\title{
Sponge-associated Haplosyllis (Polychaeta: Syllidae: Syllinae) from the Caribbean Sea, with the description of four new species
}

\author{
PATRICIA LATTIG ${ }^{1,2}$ and DANIEL MARTIN ${ }^{1}$ \\ ${ }^{1}$ Centre d'Estudis Avançats de Blanes (CEAB-CSIC), Carrer d'accés a la Cala Sant Francesc 14, \\ 17300 Blanes, Girona, Catalunya, Spain. \\ ${ }^{2}$ Departamento de Biología (Zoología), Laboratorio de Biología Marina e Invertebrados, Facultad de Ciencias, \\ Universidad Autónoma de Madrid, calle Darwin 2, 28049 Canto Blanco, Madrid, Spain. \\ E-mail: plattig@gmail.com; dani@ceab.csic.es.
}

\begin{abstract}
SUMMARY: The present paper reports results from the study of a wide collection of specimens of the genus Haplosyllis (Polychaeta: Syllidae: Syllinae) obtained mainly from sponges of different Caribbean regions (Barbados, Bahamas, Belize, Bermudas, Colombia and Venezuela). Four new species are herein described and illustrated. H. aplysinicola n. sp., the most common Caribbean species, found only in species of genus Aplysina; H. chaetafusorata n. sp., found inside the sponge Verongula rigida and characterized by having traces of fusion between blade and shaft on mid-body and posterior chaetae; $H$. navasi $\mathrm{n}$. sp., found in Colombian waters inside the sponge Ircinia strobilina and characterized by having mid-body dorsal cirri of all similar in length and by the broad acicula and proventriculum; and H. niphatesicola n. sp., collected inside sponges of genus Niphates and characterized by alternating long and short mid-body cirri, round dorsal granules throughout, and broad posterior acicula. Finally, $H$. cephalata and $H$. gula are registered for the first time in Colombian waters, and new information about their habitat is provided. Current knowledge on the relationships between the symbiotic Haplosyllis and their hosts known to date is discussed.
\end{abstract}

Keywords: Haplosyllis, new species, endosymbiosis, sponge hosts, Caribbean Sea.

RESUMEN: Haplosyllis (Polychaeta: Syllidae: Syllinae) asociados a esPonjas del mar Caribe, con la DescripCIÓN DE CUATRO ESPECIES NUEVAS. - Este artículo es el resultado del estudio de una amplia colección de muestras del género Haplosyllis (Polychaeta: Syllidae: Syllinae) que se obtuvieron principalmente de esponjas de diferentes regiones del Caribe (Barbados, Bahamas, Belize, Bermudas, Colombia y Venezuela). Se describen e ilustran cuatro especies nuevas. $H$. aplysinicola n. sp., una especie muy común para el Caribe, encontrándose únicamente en especies del género Aplysina; $H$. chaetafusorata n. sp., encontrada dentro de la esponja Verongula rigida y se caracteriza por tener trazos de unión entre el mango y el artejo de las sedas posteriores y de la región media; $H$. navasi $\mathrm{n}$. sp., hallada en aguas colombianas dentro de la esponja Ircinia strobilina, y se caracteriza por tener cirros dorsales de similar tamaño en la región media, y porque tanto la acícula como el proventrículo son muy anchos, y H. niphatesicola n. sp., encontrada dentro de especies del género Niphates, caracterizándose por la alternancia entre cirros cortos y largos en la región media, la presencia de gránulos redondeados dorsales en todo el cuerpo, y la acícula ancha posterior. Finalmente, $H$. cephalata y $H$. gula, se citan por primera vez en aguas colombianas y se aporta nueva información sobre su hábitat. Finalmente, se discute el estado actual del conocimiento sobre las relaciones entre las especies simbiontes de Haplosyllis y sus huéspedes conocidos.

Palabras clave: Haplosyllis, especies nuevas, endosimbiosis, esponjas huésped, mar Caribe.

\section{INTRODUCTION}

The genus Haplosyllis Langerhans, 1879 (Polychaeta, Syllidae, Syllinae) is very complex despite its apparent morphological simplicity. Up to end of decade
1990, the genus included about 12 species, most only known from a few reports (even the original alone), and an apparently cosmopolitan one, $H$. spongicola (Grube, 1855), with about 13 synonymies and more than 350 reports worldwide (Licher, 1999). The taxo- 
nomic position of all previously described species, synonymies, and subspecies was revised by Lattig and Martin (2009) on the basis of all available type material. Subsequently, they analyzed the Haplosyllis fauna from different geographic regions and described eight new species: two from the Canary Islands and the Mediterranean Sea (Lattig et al., 2007), four from Indonesia (Lattig et al., 2010a) and three from Australia (Lattig et al., 2010b). The previous description of four additional species from Micronesia (Sardá et al., 2002), the Canary Islands (Martin et al., 2002), Japan (Aguado et al., 2006) and Argentina (Paola et al., 2006) configured the current knowledge on the worldwide diversity of Haplosyllis. More recently, two additional populations from the Red Sea and the Indian Ocean found by Magnino and Gaino (1998) also proved to be new species (Lattig and Martin, 2011).

The present paper describes four new species from the Caribbean region and is the last contribution resulting from the $\mathrm{PhD}$ of the first author, which pointed out the extremely high diversity of Haplosyllis. The genus is now formed by 32 species, but this number is expected to increase as the fauna of other regions is studied.

Most previous taxonomic controversy involving Haplosyllis species has now been solved. For instance, Haplosyllis and Trypanoseta have been synonymized and the type species, $H$. spongicola, is no-longer considered as cosmopolitan. However, a few questions still remain open, such as the presence of an $\mathrm{H}$. spongicola-like species in Australian waters and the existence of the H. djiboutiensis species-complex (Lattig et al., 2010b). These problems seem unsolvable morphologically, requiring future molecular approaches.

All these recent studies also revealed important ecological information, such as the existence of nonsymbiotic species (e.g. Haplosyllis spongicola) and the different degrees of specificity in relationships of the symbiotic species with their host (either sponges or gorgonians). Some available materials also revealed differences in the reproductive phases (i.e. the stolons), which may be either acephalous (without prostomial appendages and with pairs of parapodial ocular spots) or cephalic (with different types of cephalic appendages and without parapodial spots). Together with a molecular approach, this type of information (still lacking for many species) may be the key to assessing the phylogeny of the genus in the near future and, as happened with the specific diversity, Haplosyllis could prove to be phylogenetically more complex than is currently accepted.

Like most regional faunas, the Haplosyllis from the Caribbean Sea have been poorly studied. However, 5 species are known to date: H. cephalata Verrill, 1900; H. agelas Uebelacker, 1982; H. gula Treadwell, 1924; and $H$. streptochepala Grube 1857. The last two were synonymized to $H$. spongicola by Licher (1999) and later recovered as valid species and re-described by Lattig and Martin (2009). Two additional descriptions of an H. spongicola and Geminosyllis sp. 1 were done by Uebelacker (1984). However, according to their descriptions and illustrations, these assignments must be disregarded and the populations are tentatively included within some of the species described herein.

The present paper results from the study of a wide collection of specimens of Haplosyllis obtained mainly from sponges of different Caribbean regions (Barbados, Bahamas, Belize, Bermudas, Colombia and Venezuela). As a result, newly collected material of $H$. cephalata helped to verify the diagnostic characters and added new information on its morphology and habitat (impossible to assess from the type material), and the specific association of $H$. gula with its host sponge Neofibularia nolitangere (Duchassaing and Michelotti, 1864) are reported for the first time for Colombian waters. In addition, four new species are described, all associated with host sponges: Haplosyllis aplysinicola. n. sp., likely the most common Caribbean species specifically associated with Aplysina spp.; Haplosyllis chaetafusorata n. sp., associated with Verongula rigida (Esper, 1794); Haplosyllis navasi $\mathrm{n}$. sp., associated with Ircinia strobilina (Lamarck, 1816); and Haplosyllis niphatesicola $\mathrm{n}$. sp., associated with Niphates erecta Duchassaing and Michelotti, 1864.

\section{MATERIALS AND METHODS}

The Colombian sponges were collected by SCUBA diving at 6-15 $\mathrm{m}$ depth along the coast of Punta Betín, Santa Marta Bay on January 23 of 2006 by P. Flórez, G. Navas, S. Zea and P. Lattig, with the help of the "Instituto de Investigaciones Marinas y Costeras" (INVEMAR). The bottoms of the bay are characterized by the presence of small colonies of corals and gorgonians, and receive the direct influence of the Santa Marta Port. Small fragments of twenty different sponge species were cut with a knife and kept isolated in closed plastic bags with clean seawater for about one hour (to force the Haplosyllis specimens to emerge from the host sponge due to the progressive reduction of the oxygen levels). In the laboratory the polychaetes were sorted, then fixed in a $4 \%$ formalin sea-water solution and then preserved in $70 \%$ ethanol for taxonomic observations. Several worms were kept in absolute ethanol for future molecular studies.

The specimens of Haplosyllis from Bahamas (off Lee Stocking Island, South Exuma Cays, Great Bahama Bank, $13^{\circ} 46^{\prime} \mathrm{N}, 75^{\circ} 05^{\prime} \mathrm{W}$ ) and Barbados (off Holetown, $13^{\circ} 11^{\prime} 3^{\prime}$ 'N, 59 $38^{\prime} 5^{\prime}$ 'W) were collected from sponges of genus Aplysina by M. Maldonado (CEAB-CSIC) (Maldonado and Young 1998a, b) and H.M. Reiswig (Reiswig, personal loan; Tsurumy and Reiswig, 1973). The specimens from Belize were collected by E. Ballesteros (CEAB-CSIC) on December 1999 between 10 and $15 \mathrm{~m}$ depth from different host sponges, and the specimens from Venezuela (Morrocoi National Park, at Boca Seca station) were collected by G. San Martín (UAM) and M. Capa (AM). 
Observations were made using an Olympus SZ30 stereomicroscope and an Olympus $\mathrm{CH} 30$ high power microscope. Drawings were made using a camera lucida. Scanning electron microscope (SEM) images were taken at the "Servei de Microscopia Electrònica" of the "Institut de Ciències del Mar" of Barcelona (ICM, CSIC). All specimens were prepared using standard SEM procedures.

The terms used for chaetal characters are found in Martin et al. (2003) and Lattig and Martin (2009). The chaetal characters herein used to describe and compare chaetae are: length of main fang (LMF) similar in length or longer than chaetal width (SW); upper side (US) of main fang (MF) with or without denticles; and midjoining point (MJP) between teeth and MF, described as curved (usually short) or straight (perpendicular to MF, being short or long). Proximal and distal apical teeth were all equal in size, distal thin and shorter, or proximal smaller.

The following institutional abbreviations are used in the Examined Material sections: MNCN (Museo Nacional de Ciencias Naturales, Madrid, Spain), USNM (United States Museum, Smithsonian Institution, United States), YPM (Peadbody Museum of Natural History, Yale University, United States).

\section{RESULTS}

Family SylLidAe Grube, 1850

Subfamily SYLLINAE Grube, 1850

Genus Haplosyllis Langerhans, 1879

Haplosyllis Langerhans, 1879: 527

Trypanosyllis (Trypanoseta) Imajima and Hartman, 1964: 129. Geminosyllis Imajima, 1966: 233.-Kudenov and Harris, 1995: 71, Fig. 1.26.-Lattig et al., 2007: 561-562.

Type species. Syllis spongicola Grube, 1855.

Haplosyllis aplysinicola $\mathrm{n} . \mathrm{sp}$. (Figs. 1A-H, 2A-F, 3A-D, 4A-B)

Examined material. Colombia, Santa Marta, Punta de Betín. Holotype INV-ANE 3455. 130 Paratypes (plus two for SEM) INV-ANE 3456 and 80 Paratypes INV-ANE 3457: collected inside Aplysina insularis, 6-8 $\mathrm{m}$ depth.

Additional examined material. Colombia, Santa Marta, Punta de Betín: 130 specimens INV-ANE 3458: collected inside Aplysina lacunosa, $10 \mathrm{~m}$ depth; 3 specimens INV-ANE 3460: collected inside A. cauliformis, 6-8 m depth. Bahamas, Great Bahama Bank, South Exuma Cays, off Lee Stocking Island: 100 specimens MNCN 16.01/13185 collected inside A. bathyphyla, 114 m depth; 40 specimens MNCN 16.01/13186 inside A. fistularis, 18-200 m depth; 100 specimens MNCN 16.01/13191 inside Aplysina sp. 18-200 m depth; 20 specimens MNCN 16.01/13189 inside A. corrugata, $18-200 \mathrm{~m}$ depth. Barbados, Holetown, $13^{\circ} 11^{\prime} \mathrm{N} 38^{\prime}$ ' $\mathrm{W}$, collected inside Aplysina spp.: 300 specimens MNCN 16.01/13187; 2 specimens (for SEM) MNCN 16.01/13188; 63 specimens MNCN 16.01/13190; 200 specimens MNCN 16.01/13192; 150 specimens MNCN 16.01/13193. Belize inside fragments of Aplysina spp: 31 specimens (Be-E) MNCN 16.01/13194; 170 specimens (Be-5) MNCN 16.01/13195; 285 specimens (Be-7) MNCN 16.01/13196; 76 specimens (Be-13) MNCN 16.01/13197. Venezuela: Morrocoy National Park, inside Aplysina spp: 15 specimens, MNCN
16.01/13198; 42 specimens MNCN 16.01/13199; 32 specimens MNCN 16.01/13200.

Description. Body translucent, slender, fragile, small. Holotype measures $2.4 \mathrm{~mm}$ long, about $0.3 \mathrm{~mm}$ wide, for 25 segments. Paratypes 2-5 mm long, for 23-32 segments, about $0.3 \mathrm{~mm}$ wide excluding parapodia, widest at proventricle level (Figs 1A, 2A). Preserved specimens pale cream or purple (as host sponge), with scarce small dorsal granules throughout body. Prostomium subpentagonal, wider than longer, with 2 pairs of small red eyes in trapezoidal arrangement. Median antenna twice as long as lateral ones (13-27 and 9-18 articles, respectively); median antennae inserted on middle of prostomium, between eyes, lateral antennae on anterior margin (Fig. 1A). Palps long, broadly triangular, fused at their bases but separated all along their length; rows of cilia make up the sensory organs on ventral upper side (Fig. $2 \mathrm{C}$ ). Nuchal organs not seen. Pharynx orange, as wide as proventricle, extending through 5-6 segments; with large anterior tooth, crown of 12 soft papillae and inner ring of cilia (Fig. 2B); groups of cilia make up sensory organs on ventral side of papillae. Proventricle cylindrical, dark-brown, about $0.2 \mathrm{~mm}$ wide, extending through 2-5 segments, with 27-33 muscle cell-rings (Fig. 1A). Peristomium well defined, shorter than subsequent segments. Dorsal tentacular cirri longer than ventral ones (11-23 and 4-13 articles, respectively). Dorsal cirri slender, similar to antennae and tentacular cirri. First cirri longer than remaining ones (15-30 articles), second, third and fourth gradually longer (6-12, 9-17 and 8-28 articles, respectively); fifth short (5-13 articles); after proventricle, cirri alternate with long (6-11 articles) and short (2-7) (Figs 1A, 2D); gradually shorter toward posterior end (1-7 articles) (Fig. 1B); mid-body cirri do not exceed body width. Ventral cirri digitiform, similar to or shorter than parapodial lobes (Fig. 1C-D). Chaetae all bidentate, 2-3 per parapodia, all similar in shape, with short spines on US of MF; LMF similar in length to SW; MJP curved, short, apical teeth short, with wide angle (Figs 1E, G, 2E-F). Two aciculae in each parapodium, small, with short curved tip, upwards directed, duck-tip shaped backwards (Fig. 1F, H). Pigidium with two short cirri (1-8 articles) (Fig. 1B).

Reproduction. Haplosyllis aplysinicola n. sp. reproduces by cephalic stolons without parapodial ocular spots. In the specimens from Colombia and Venezuela, the female reproductive bodies were still attached to the parental individual, the last 8-12 segments containing 12-26 intracoelomic oocytes (8-26 $\mu \mathrm{m}$ in diameter). In Barbados, the population was in a more advanced reproductive stage, with both male and female stolons still attached to the respective parental individuals, and some already detached female stolons having a well-distinguishable head with two small semi-spherical appendages (likely palps) and 2 pairs of reddish eyes (anteriormost larger than posterior-most), 3-4 chaetae similar to those of non-reproductive individuals and a notopodial tuft of capillary (swimming) chaetae (Fig. 3A-D). 


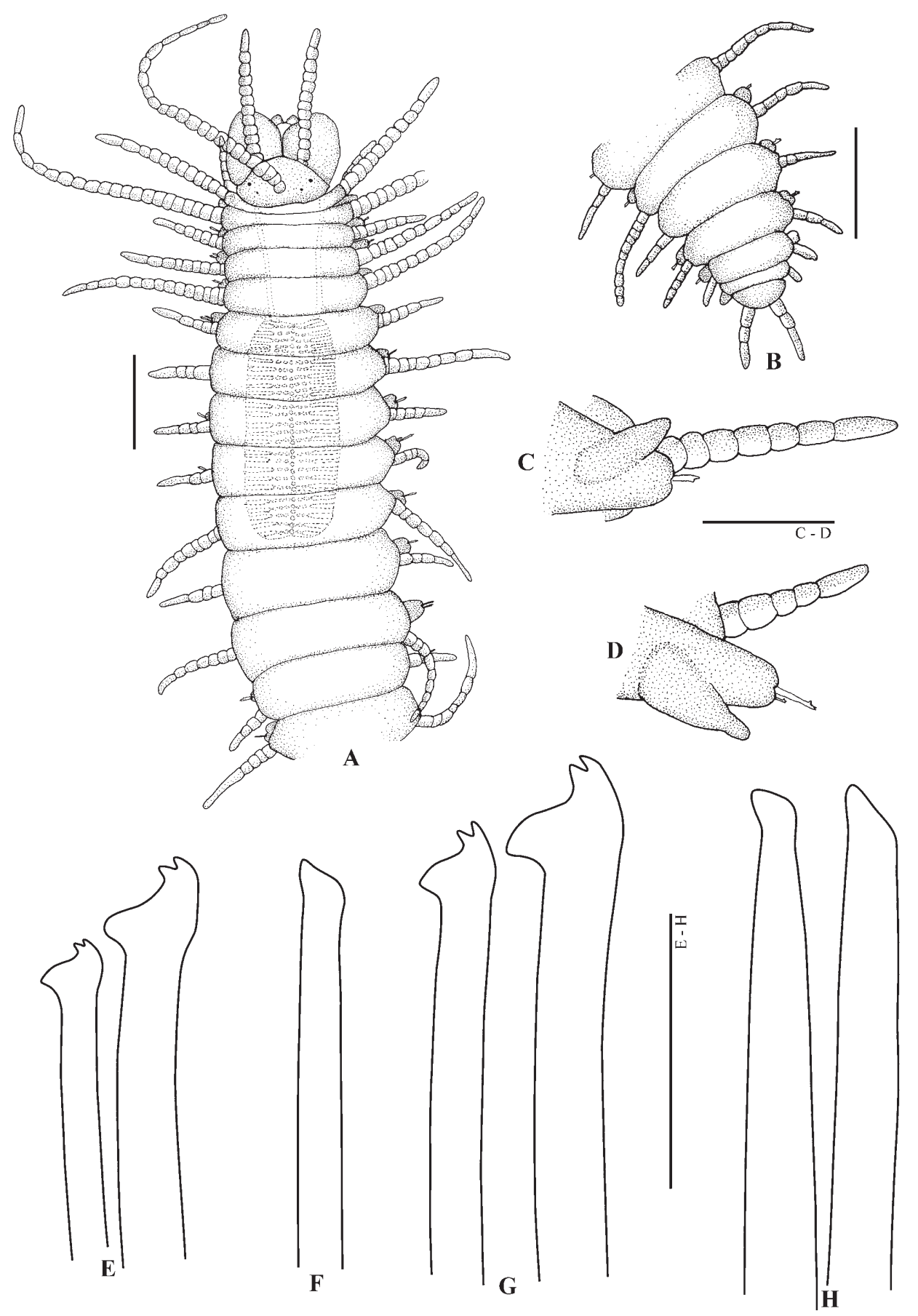

FIG. 1. - Hand-drawing of Haplosyllis aplysinicola $\mathrm{n}$. sp. A, anterior end, dorsal view. B, posterior end, dorsal view. C, anterior parapodium, chaetiger 5. D, posterior parapodium. E, anterior chaetae, chaetiger 4. F, anterior acicula, chaetiger 4. G, mid-body chaetae. H, mid-body aciculae. Scale bars: A-B $(200 \mu \mathrm{m})$, C-D $(100 \mu \mathrm{m})$, E-H $(20 \mu \mathrm{m})$. Holotype INV-ANE 3455.

Two different types of juveniles were found in Belize. The first ones resembled small adults having all appendages proportionally smaller (Fig. 4A). The second ones differed in having the anterior-most region markedly thinner than the posterior one (Fig. 4B). These two types correspond to two reproductive strategies, sexual in the former and asexual in the latter (i.e. by fragmentation and further regeneration of the anterior end). Asexual reproduction by fragmentation is known of only three syllid species, Syllis gracilis (Okada, 1929; Boilly and Thibaut, 1974), S. cf. armillaris (López et al., 2001) and Procerastea halleziana (Allen, 1923; Langhammer, 1928; Genzano and San Martín, 2002). The last two have been reported as symbionts from hermit crabs and hydroids, respectively (López et al., 2001; Genzano and San Martín, 2002). 

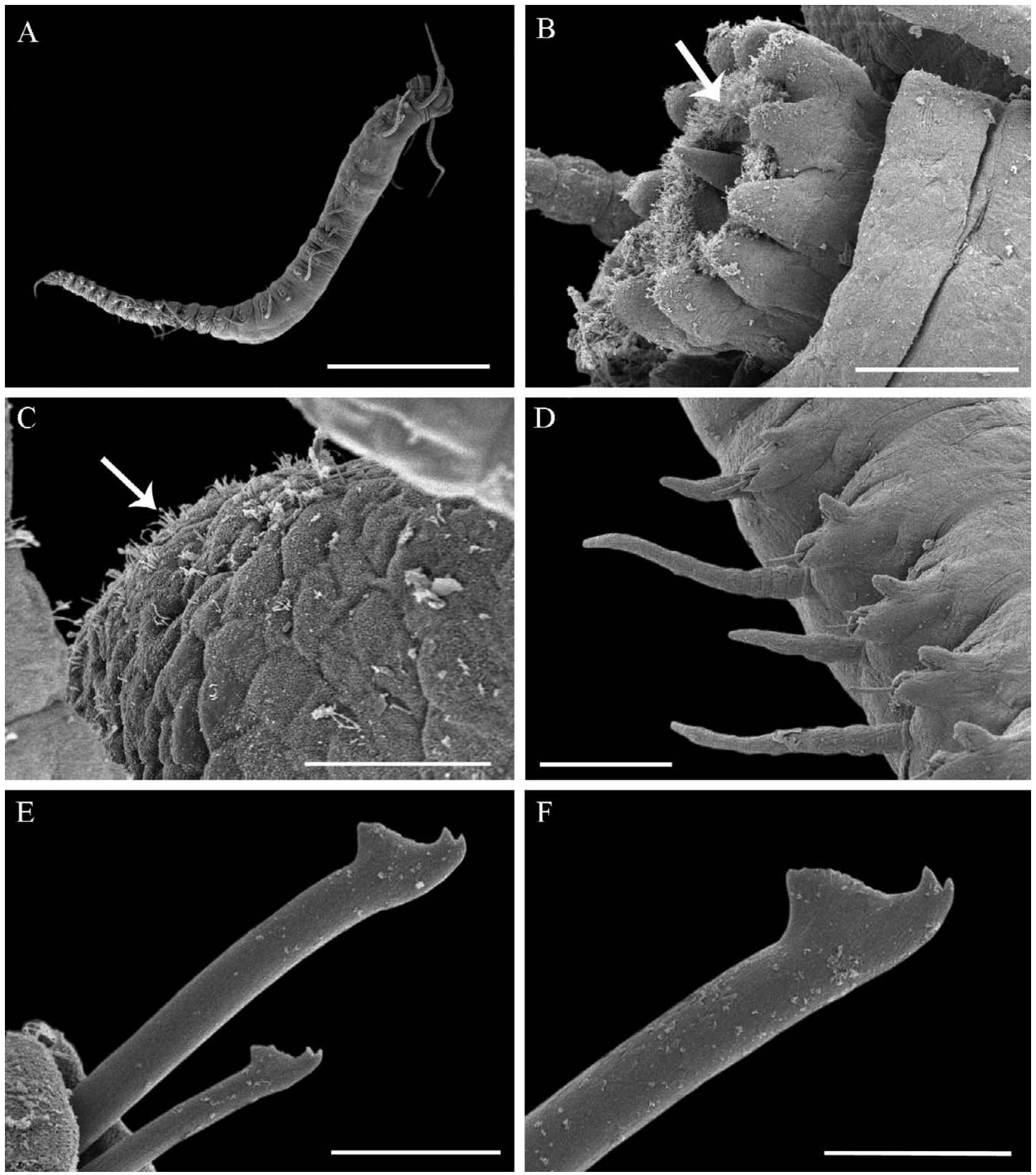

FIG. 2. - SEM micrographs of Haplosyllis aplysinicola n. sp. A, whole body, ventral view. B, pharynx showing anterior tooth, soft papillae and ring of cilia (indicated by arrow). C, upper-ventral side of palps, arrow points on cilia. D, mid-body parapodia, cirri alternating with long and short. E, anterior chaetae, chaetiger 5. F, mid-body chaeta. Scale bars: A (1 mm), B (500 um), C (20 $\mu \mathrm{m}), \mathrm{D}(100 \mu \mathrm{m}), \mathrm{E}-\mathrm{F}(10 \mu \mathrm{m})$. Paratypes INV-ANE 3456.

Habitat. Haplosyllis aplysinicola $\mathrm{n}$. sp. is a strict sponge endosymbiont associated with species of Aplysina (see examined material for detailed list). Infestations ranged from 50 to 200 specimens in a small sponge fragment ( 1 to $5 \mathrm{~cm}^{3}$ in volume).
As mentioned above, the species may reproduce both sexually and asexually. Asexual reproduction is often associated with a colonizing strategy in symbiotic polychaetes, with the sexual recruits being the first colonizers and the new symbiotic populations rapidly proliferating 


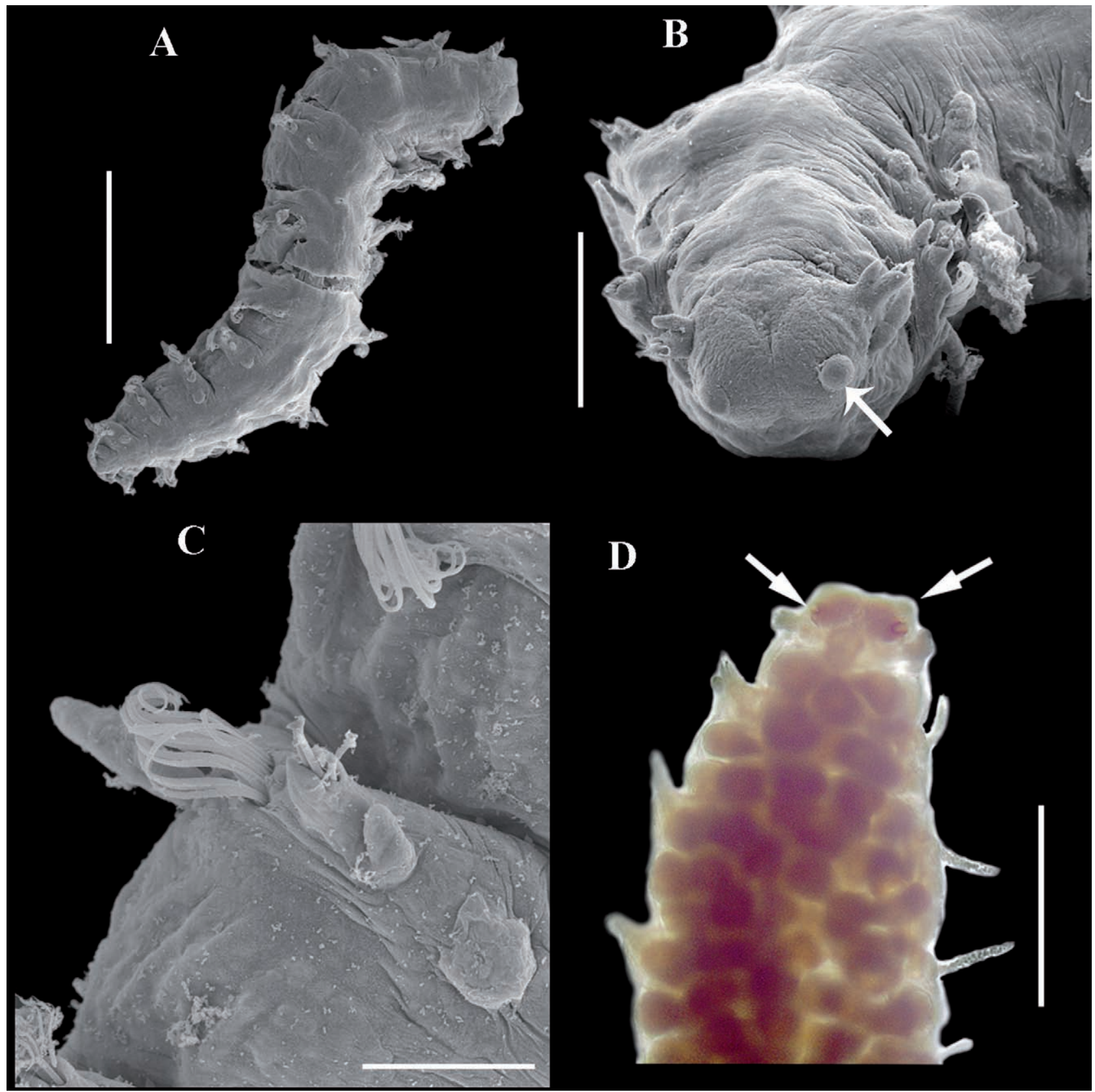

FIG. 3. - SEM micrographs of Haplosyllis aplysinicola n. sp., from Barbados. A, female reproductive body. B, detail of cephalic region, arrow points on palps. C, parapodium with swimming and normal chaetae. Light micrograph: D, female stolon with intracoelomic oocytes. Scale bars: A $(0.38 \mathrm{~mm}), \mathrm{B}(136 \mu \mathrm{m}), \mathrm{C}(50 \mu \mathrm{m}), \mathrm{D}(250 \mu \mathrm{m})$. MNCN 16.01/13188.

inside the host thanks to the ability of reproducing by fragmentation (Martin and Britayev 1998).

Distribution. Caribbean Sea: Bahamas, Barbados, Belize, Colombia and Venezuela.

Etimology. The name Haplosyllis aplysinicola n. sp. refers to the host sponges of genus Aplysina in which the new species were found.

Remarks. Haplosyllis aplysinicola n. sp. is characterized by the broad chaetae with MJP short and curved, acicula with curved duck-shaped tip, and mid-body cirri alternating with short and long. $H$. aplysinicola $\mathrm{n}$. sp. can be easily distinguished from $H$. cephalata by the strong, curved acicula and short mid-body cirri, and from $H$. gula by its long MJP and broad pharynx. Aciculae of $H$. aplysinicola $\mathrm{n}$. sp. are similar to those of Haplosyllis navasi n. sp. (Fig. 5C-D) (see below), but differ in having the mid-body dorsal cirri equal in length and the apical teeth shorter (Fig. 5A-B). H. aplysinicola n. sp. is similar to $H$. chaetafusorata n. sp. and $H$. niphatesicola n. sp. (see below) in alternation of cirri length 


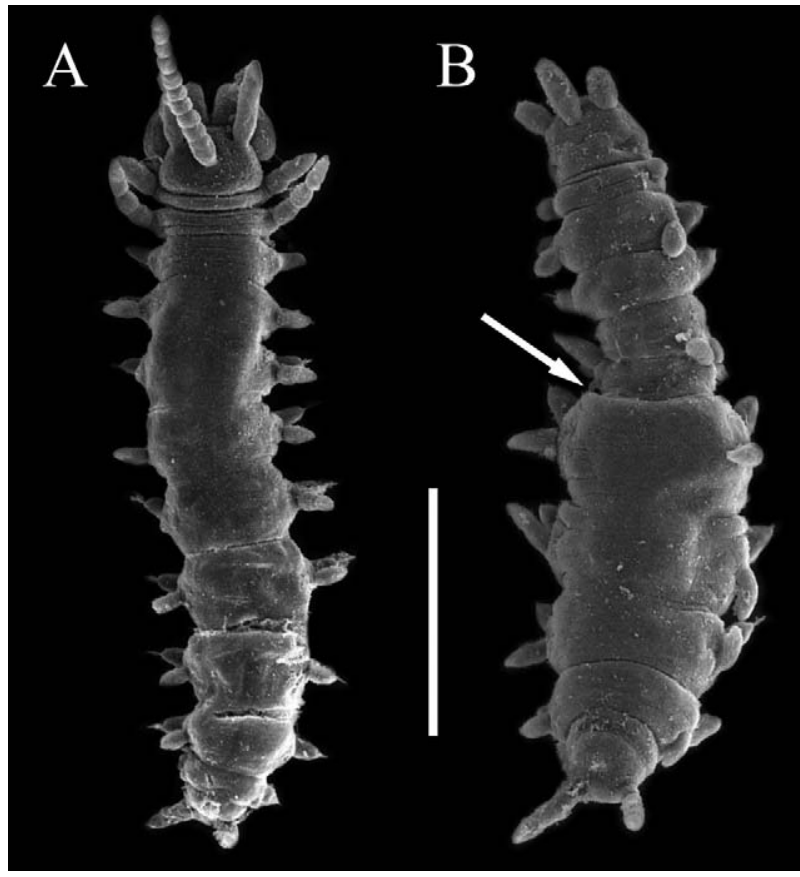

FIG. 4. - SEM micrographs of Haplosyllis aplysinicola n. sp. from Belize A, juvenile resulting from sexual reproduction. B, juvenile probably resulting from asexual reproduction; arrow indicates the origin of regenerating anterior region. Scale bars A $(230 \mu \mathrm{m}), \mathrm{B}$ $(150 \mu \mathrm{m})$. Personal collection D. Martin.

and LMF (but see corresponding remarks for comparative details).

Haplosyllis aplysinicola $\mathrm{n}$. sp. resembles $H$. basticola in having small bodies and chaetae with MJP short and curved, as well as in being a strict sponge endosymbiont. However, it differs in having duck-tip shaped aciculae, aplysinid sponges as hosts (Ianthellidae in H. basticola) and Caribbean distribution (Indo-
Pacific in $H$. basticola). To date, these two species and H. chamaeleon are also the only Haplosyllis known to have cephalic stolons and lack parapodial ocular spots. However, the stolons differ in having cephalic appendages as semispherical palps in $H$. aplysinicola n. sp. (Fig. 3B, D) and as digitiform antennae in $\mathrm{H}$. basticola (Lattig et al., 2010b Fig. 3B-C).

\section{Haplosyllis cephalata Verrill, 1900} (Figs. 6A-L, 7A-F)

Haplosyllis cephalata Verrill, 1900: 613-614.-Licher, 1999: 280.—Lattig and Martin, 2009: 13, Fig. 8.

Examined material. Colombia, Santa Marta, Punta de Betín. 120 specimens (plus 2 for SEM) INV-ANE 3461: inside Ircinia campana, 6-8 $\mathrm{m}$ depth.

Comparative examined material. Bermudas, Caribbean Sea. 4 syntypes YPM 22543; 6 syntypes YPM 22544; 3 Syntypes YPM 23002 .

Description. Body long, slender (Figs 6A, 7A), 6-9 $\mathrm{mm}$ long, about $0.3 \mathrm{~mm}$ wide excluding parapodia, for 26-43 segments. Living and preserved specimens whitish, with round dorsal granules throughout (Fig. 6A-E). Prostomium oval, as wide as long, with two pairs of small red eyes in trapezoidal arrangement. Median antenna inserted on middle of prostomium (13-21 articles); lateral antennae on anterior margin (7-15 articles). Palps long, broadly triangular, fused at their bases, but separated all along their length. Nuchal organs as lateral groups of cilia between prostomium and peristomium. Pharynx orange, extending through 4-6 segments, slightly thinner than proventricle, with large anterior tooth and crown of 11-12 soft papillae (Fig. 7B), inner ring of cilia not seen. Proventricle dark-brown, cylindrical, 0.6-0.9 mm long, about $0.3 \mathrm{~mm}$ wide, extending through 3-6 segments, with 33-
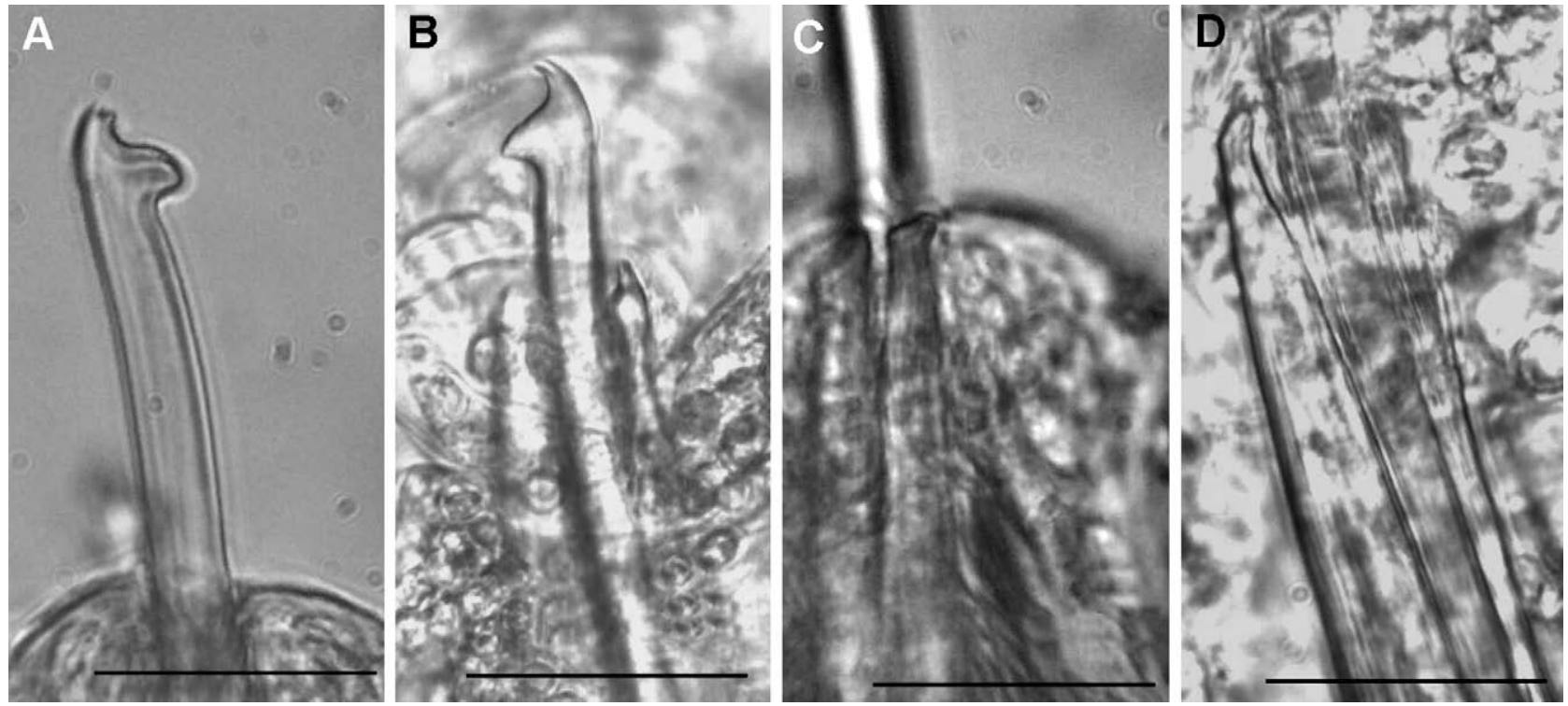

FIG. 5. - Comparative photographs of mid-body chaetae and aciculae of Haplosyllis aplysinicola n. sp. (A, C) (INV-ANE 3456) and Haplosyllis navasi $\mathrm{n}$. sp. (B, D) (INV-ANE 3454). Scale bars $20 \mu \mathrm{m}$. 

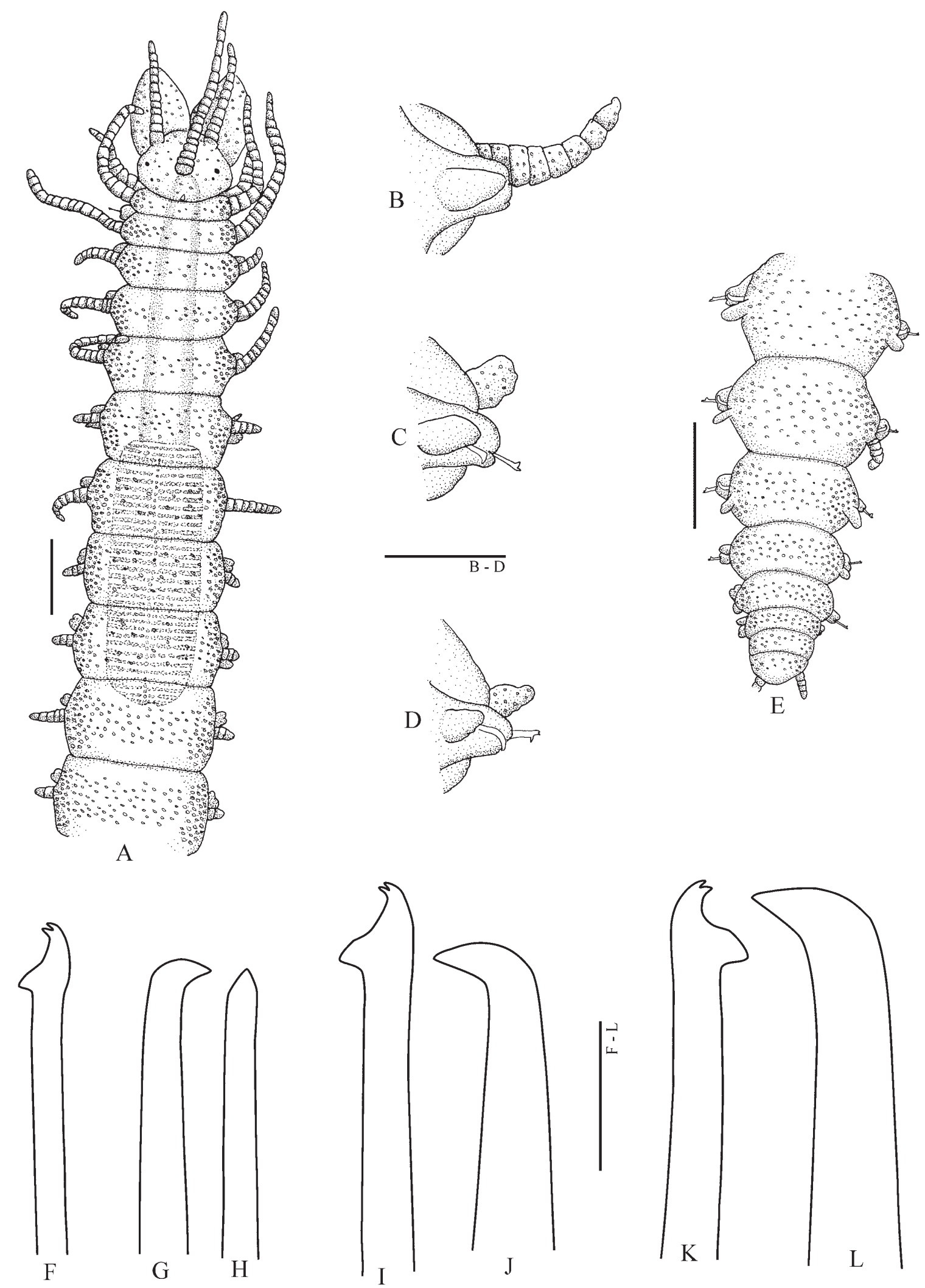

FIG. 6. - Hand-drawing of Haplosyllis cephalata. A, anterior end, dorsal view. B, anterior parapodium, chaetiger 2. C, mid-body parapodium of post-proventricular region. D, posterior parapodium. E, posterior end, dorsal view. F, chaeta of chaetiger 3. G, acicula with curved tip, chaetiger 3. H, acicula with straight tip, chaetiger 3. I mid-body chaeta. J, mid-body acicula. K, posterior chaeta. L, posterior acicula. Scale bars: A, E $(200 \mu \mathrm{m}), \mathrm{B}-\mathrm{D}(100 \mu \mathrm{m})$, F-L $(20 \mu \mathrm{m})$. INV-ANE 3461. 

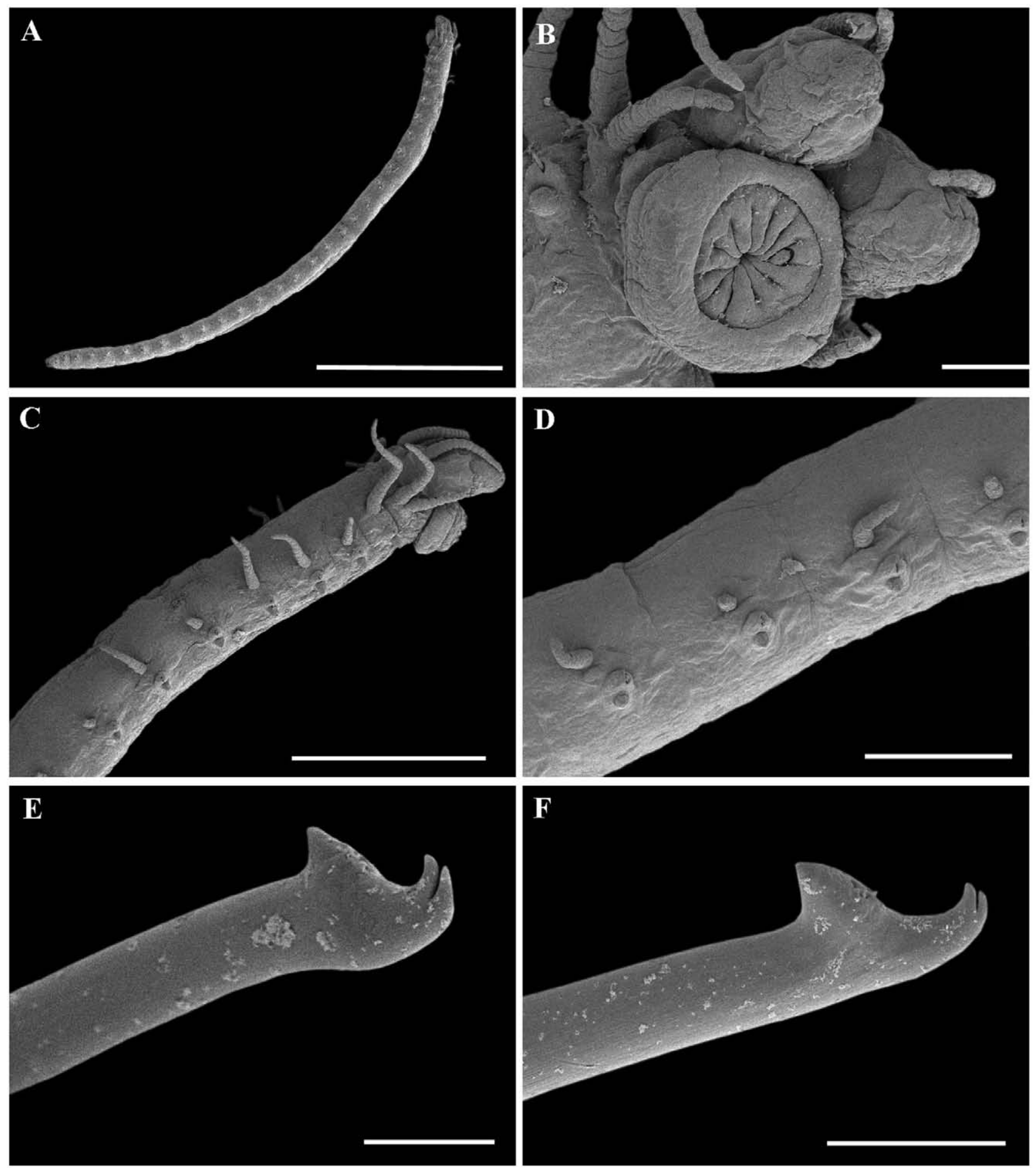

FIG. 7. - SEM micrographs of Haplosyllis cephalata. A, whole body, lateral view. B, pharynx with 12 soft papillae. C, anterior end, lateral view, showing first seven chaetigers. D, mid-body parapodia with short cirri. E, anterior chaetae, chaetiger 2. F, posterior chaeta. Scale bars: A $(2 \mathrm{~mm}), \mathrm{B}(100 \mu \mathrm{m}), \mathrm{C}(500 \mu \mathrm{m}), \mathrm{D}(200 \mu \mathrm{m}), \mathrm{E}(5 \mu \mathrm{m}), \mathrm{F}(10 \mu \mathrm{m})$. INV-ANE 3461.

47 muscle cell-rings. Peristomium well defined, shorter than subsequent segments. Dorsal tentacular cirri longer than ventral ones (5-18 and 6-9 articles, respectively). Anterior dorsal cirri slender, similar to antennae and tentacular cirri. First dorsal cirri longer than remaining ones (12-25 articles), second, third and fourth gradually longer (5-11, 7-14 and 8-16 articles, respectively); fifth short (2-7 articles), sixth slightly longer (5-10 articles) (Figs 6A, 7C). Subsequent cirri much smaller, with 1-4 articles (Figs 6A, E, 7D). Ventral cirri digitiform, broad, similar to or smaller than parapodial lobes, gradually decreasing in length to posterior end (Fig. 6B-D). Cha- 

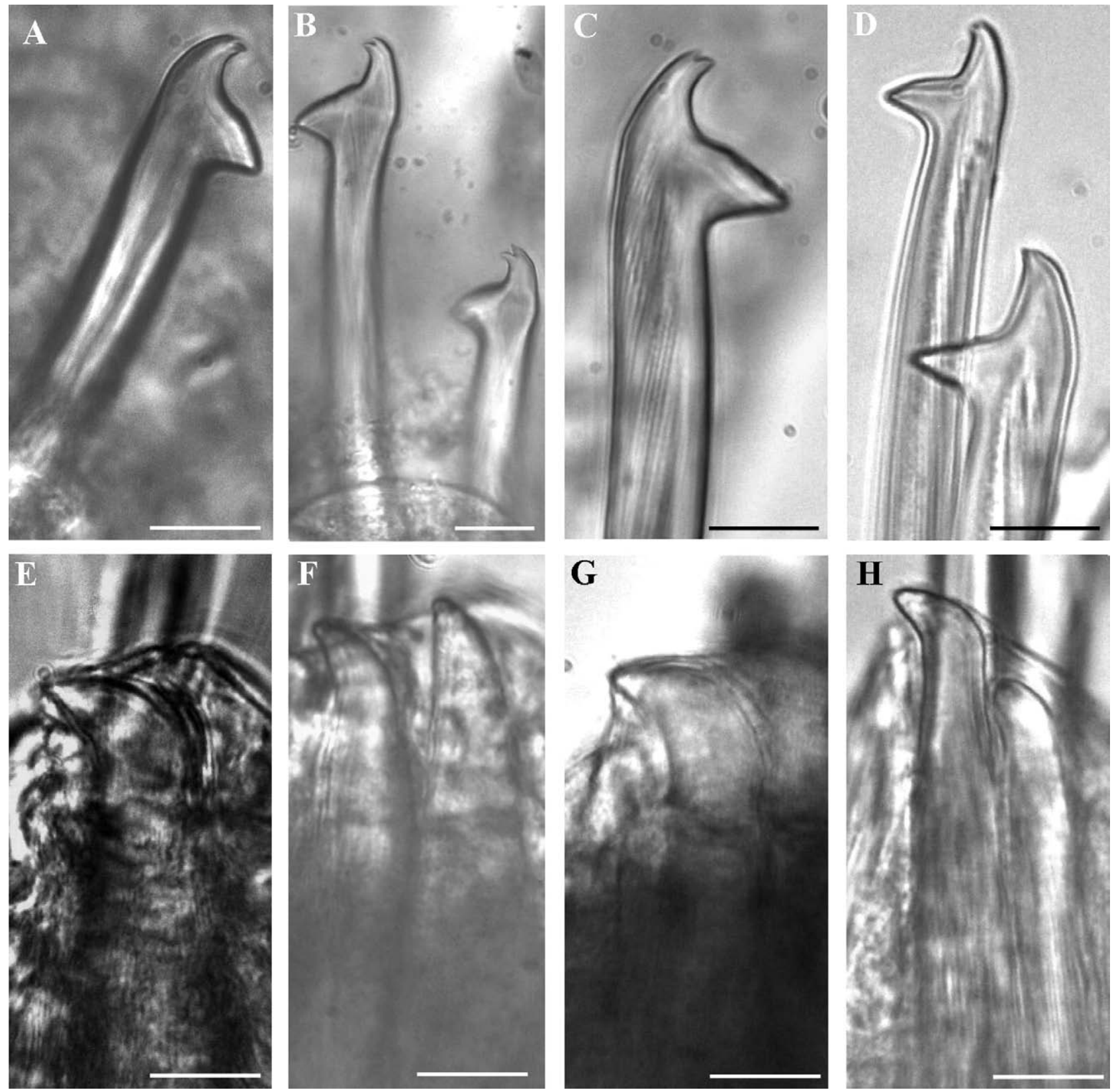

FIG. 8. - Comparative photographs of mid-body chaetae and aciculae of Haplosyllis cephatalata (A, E) (INV-ANE 3461.), Haplosyllis chaetafusorata n. sp. (B, F) (INV-ANE 3468), Haplosyllis niphatesicola n. sp. (C, G) (INV-ANE 3464), and Haplosyllis sp. (D, H) (INV-ANE 3466). Scale bars $10 \mu \mathrm{m}$.

etae all bidentate, 1-2 per parapodia, all similar in shape, anterior ones smaller (Figs 6F; 7E). Mid-body and posterior ones with LMF similar to SW; MJP straight, short; denticles on US of MF very short; apical teeth equal in length, separated by narrow angle (Figs 6I, K; 7F). Two aciculae per anterior parapodia, one straight (Fig. 6H), the other with upwards-directed curved tip (Fig. 6G); one acicula in mid-body and posterior parapodia, broad, with upwards-directed curved tip (Fig. 6J, L). Pygidium with two short anal cirri (2-5 articles) (Fig. 6E).

Reproduction. Haplosyllis cephalata reproduces by acephalous stolons. Two female specimens had the last
9-10 segments already modified, with pairs of parapodial ocular spots and 2-3 chaetae similar to anterior ones. However, about 20 posterior segments contained oocytes (4-12 of 500-800 $\mu \mathrm{m}$ in diameter).

Habitat. More than 100 specimens were found inside a small fragment of Ircinia campana (Lamarck, 1816) between 6-8 $\mathrm{m}$ depth.

Distribution. Caribean Sea: Bermudas, Colombia.

Remarks. This is the second confirmed report for Haplosyllis cephalata, in addition to that in the origi- 
nal description. The species has broad acicula and short mid-body dorsal cirri (with only 1-4 articles). The body shape of the syntypes (from Bermudas) seems stouter than of the Colombian specimens (longer and slender), but the former were in a permanent preparation that masked their real shape. In addition, they did not show evident dorsal granules (Lattig and Martin 2009), which were easy to observe and distinguish in the Colombian specimens.

The chaetal and acicular shapes of $H$. cephalata are similar to those of $H$. chaetafusorata n. sp. and $H$. niphatesicola $\mathrm{n}$. sp. (see below), but $H$. chaetafusorata n. sp. differs in having chaetae with traces of fusion between blade and shaft, and a straight acicula (Fig. 8B, F), and $H$. niphatesicola $\mathrm{n}$. sp. in having a MF longer and with pointed tip (Fig. 8C). However, $H$. cephalata clearly differs in having mid-body cirri very short (alternating between short and long in the other two species).

Haplosyllis chaetafusorata $\mathrm{n}$. sp. (Figs. 9A-I, 10A-F)

? Haplosyllis spongicola: Uebelacker, 1984, fig. 105.

Examined material. Colombia, Santa Marta, Punta de Betín. Holotype INV-ANE 3467. 150 Paratypes (plus two for SEM) INV-ANE 3468: inside Verongula rigida, 6-8 m depth.

Description. (in parenthesis measurements for smaller specimens).

Body translucent, slender, small to mid-sized. Holotype measuring $8 \mathrm{~mm}$ long, about $0.35 \mathrm{~mm}$ wide, for 54 segments. Paratypes 3-8 $\mathrm{mm}$ long, with 25-52 segments, 0.4-0.5 (0.2) $\mathrm{mm}$ wide excluding parapodia. Wide at proventricle level, gradually tapering towards posterior end (Fig. 10A). Pale yellow when preserved. Dorsal granules scarce, more evident in smaller specimens. Prostomium subpentagonal, wider than longer, with two pairs of small red eyes in trapezoidal arrangement. Median antenna twice as long as lateral ones (7-38 and 9-21 articles, respectively), inserted on middle of prostomium, lateral antennae on anterior margin (Fig. 9A). Palps long, broadly triangular, fused at their bases but separated all along their length, with groups of cilia making up the sensory organs. Nuchal organs as lateral groups of cilia between prostomium and peristomium. Pharynx orange, as wide as proventricle, extending through 4-6 segments; with large anterior tooth; crown of soft papillae and inner ring of cilia not seen. Proventricle cylindrical, dark-brown, 0.3 0.4 (0.2) mm wide, extending through 2-5 segments, with 31-37 muscle cell-rings (Fig. 9A). Peristomium well defined, shorter than subsequent segments. Dorsal tentacular cirri longer than ventral ones, with 17-27 (10-17) and 7-13 (2-7) articles, respectively. Dorsal cirri slender, similar to antennae and tentacular cirri. First cirri longer than remaining ones (16-40 articles), second, third and fourth gradually longer
[9-16 (3-7), 14-20 (5-10) and 20-28 (11-17) articles, respectively]; fifth short [8-13 (2-6) articles], sixth long [20-28 (8-13) articles]. After proventricle, cirri alternating with long [11-18 (5-11) articles] and short [4-8 (1-4) articles] (Figs 9A, 10B); mid-body cirri do not exceed body width; posterior cirri short, with 1-5 articles (Fig. 9B). Ventral cirri digitiform, broad, similar to or shorter than parapodial lobes; gradually shorter to posterior end (Fig. 9C-D). Chaetae all bidentate, 2-3 per parapodia, anterior ones smaller, with short spines on US of MF (Figs 9F, $10 \mathrm{C}$ ), anterior and mid-body chaetae with traces of fusion between blade and shaft (Figs 9G, 10C-D); mid-body and posterior chaetae with LMF similar than SW; MJP straight; apical teeth short, distal tooth slightly smaller than proximal one; wide angle between teeth (Figs 9G; 10D-F). Two to three aciculae in mid-body and posterior segments, some broad, straight (Fig. 9H), others with small curved tip (Fig. 9I); 3-4 anterior aciculae, small, with curved tips (Fig. 9E). Pigidium with two short anal cirri (2-4 articles).

\section{Reproduction. Not known.}

Habitat. Hundreds of specimens were found inside the sponge Verongula rigida (Esper, 1794) inhabiting bottoms between 6-8 $\mathrm{m}$ depth. The Haplosyllis shared the host with 13 specimens of Branchiosyllis sp. and a few more polychaetes (i.e. cirratulids, hesionids and terebellids). As in $H$. gula and $H$. navasi n. sp., $H$. chaetafusorata $\mathrm{n}$. sp. only occurs in association with a single sponge species, suggesting a species-specific endosymbiotic association.

A previous report of a Haplosyllis (as H. spongicola) from Verongia reiswigi Alcolado, 1984 in Jamaica (Reiswig 1973 as Verongia gigantea) could also belong to this species. However, this material has not been checked, requiring future analyses for its identity. If confirmed, the specificity of the association could be specific at genus level, as in Haplosyllis aplysinicola n. sp. an endosymbiont of Aplysina spp. (see above).

Distribution. Caribbean Sea, Colombia; Jamaica (?).

Etymology. The name Haplosyllis chaetafusorata refers to the traces of fusion between blade and shaft of some chaetae, which are easily distinguishable under light microscope.

Remarks. Haplosyllis chaetafusorata n. sp. is characterized by having traces of fusion between blade and shaft on mid-body and posterior chaetae, two broad aciculae (one straight, other with small curved tips), and alternation in cirri length.

The chaetal shape of $H$. chaetafusorata n. sp. resemble those of $H$. cephalata and $H$. niphatesicola n. sp. (see below) (Fig. 8A-C, E-G), which differ in 

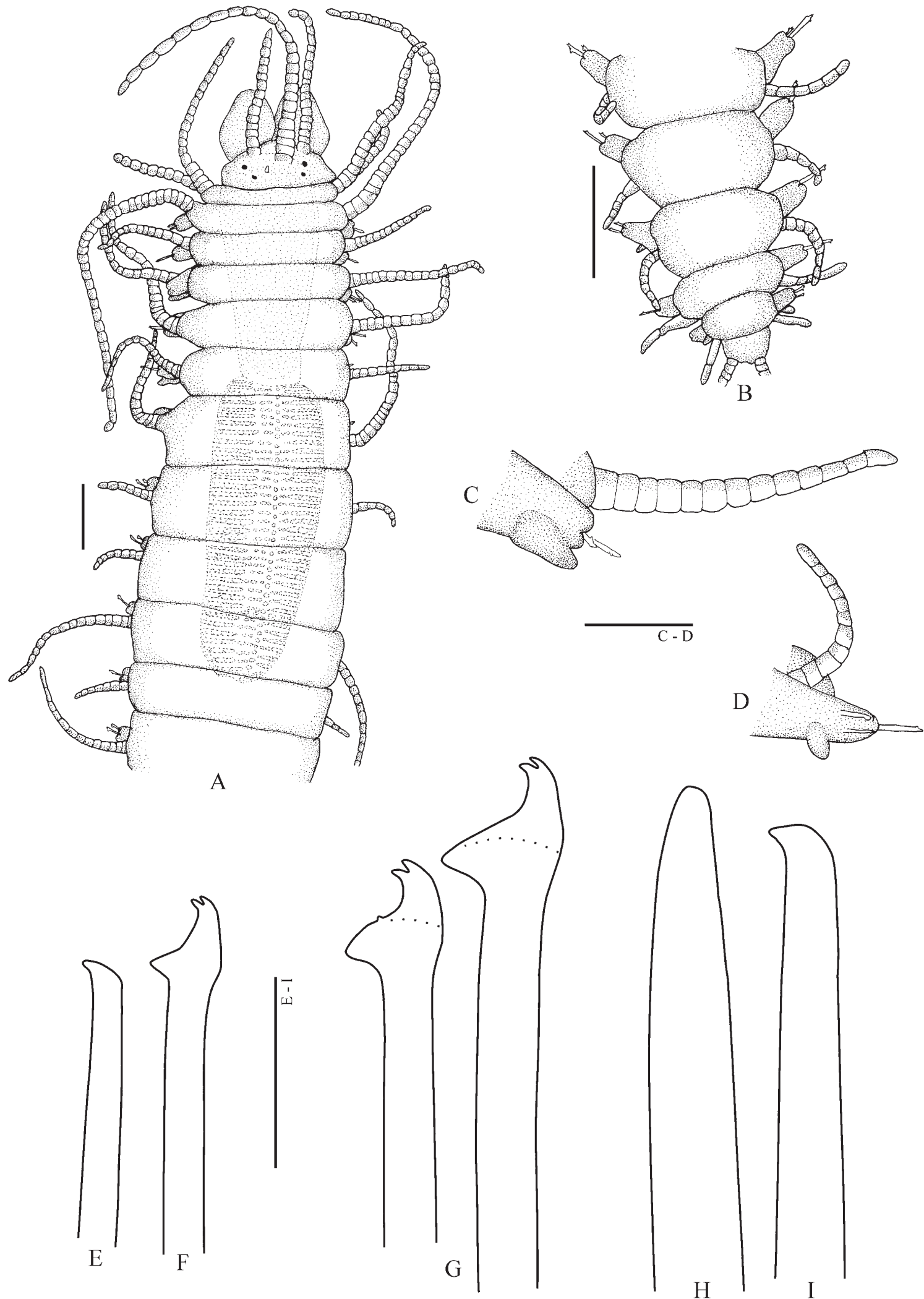

FIG. 9. - Hand-drawing of Haplosyllis chaetafusorata n. sp. A, anterior end, dorsal view. B, posterior end, dorsal view. C, anterior parapodium, chaetiger 2. D, posterior parapodium, last third chaetiger. E, anterior acicula, chaetiger 5. F, anterior chaeta, chaetiger 3. G, mid-body chaetae with traces of fusion between blade and shaft. H, mid-body straight acicula. I, mid-body acicula with curved tip. Scale bars: A-B (200 $\mu \mathrm{m}), \mathrm{C}-\mathrm{D}(100 \mu \mathrm{m}), \mathrm{E}-\mathrm{I}(20 \mu \mathrm{m})$. INV-ANE 3468 

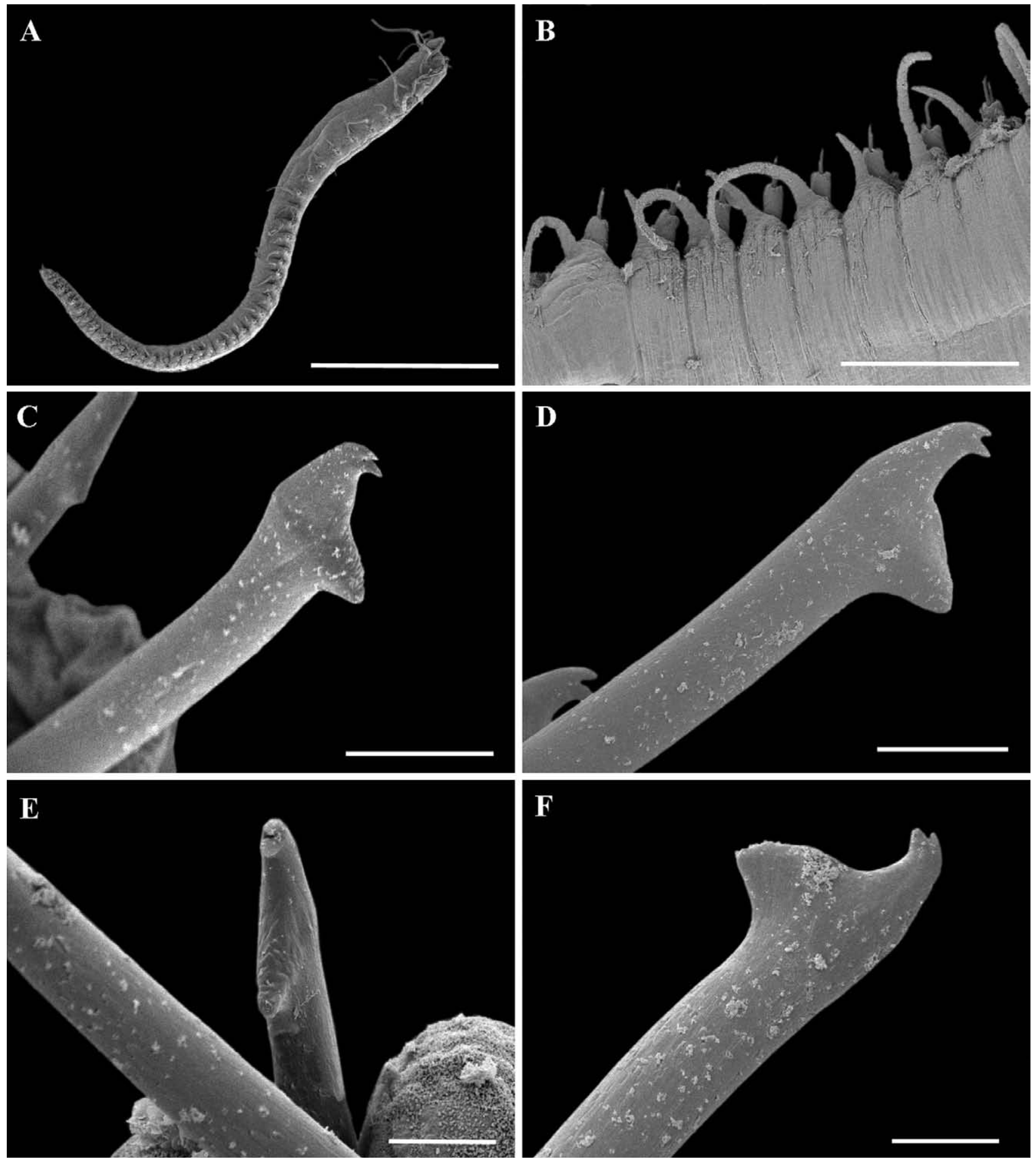

FIG. 10. - SEM micrographs of Haplosyllis chaetafusorata n. sp. A, whole body, lateral view. B, mid-body parapodia, alternating long and short cirri. C, anterior chaetae, chaetiger 4. D, mid-body chaetae. E, mid-body small chaetae, lateral view. F, posterior chaeta. Scale bars: A $(2 \mathrm{~mm}), \mathrm{B}(300 \mu \mathrm{m}), \mathrm{C}-\mathrm{D}(10 \mu \mathrm{m}), \mathrm{E}-\mathrm{F}(5 \mu \mathrm{m})$. INV-ANE 3468.

having shorter cirri $(H$. cephalata, see corresponding remarks), and round dorsal granules, chaetae without traces of fusion between blade and shaft, straight aciculae, and a more pointed main fang $(H$. niphatesicola $\mathrm{n}$. sp.). H. chaetafusorata $\mathrm{n}$. sp. may be easily distinguished from $H$. gula, which has a wider pharynx and aciculae with $90^{\circ}$ curved tip, H. navasi n. sp., which has a broad proventricle, mid-body cirri all similar in size, long apical teeth, and a different acicular shape (see below), and H. aplysinicola $\mathrm{n}$. sp., which has short MF and a different acicular shape (see above) (Fig. 5A, C). 


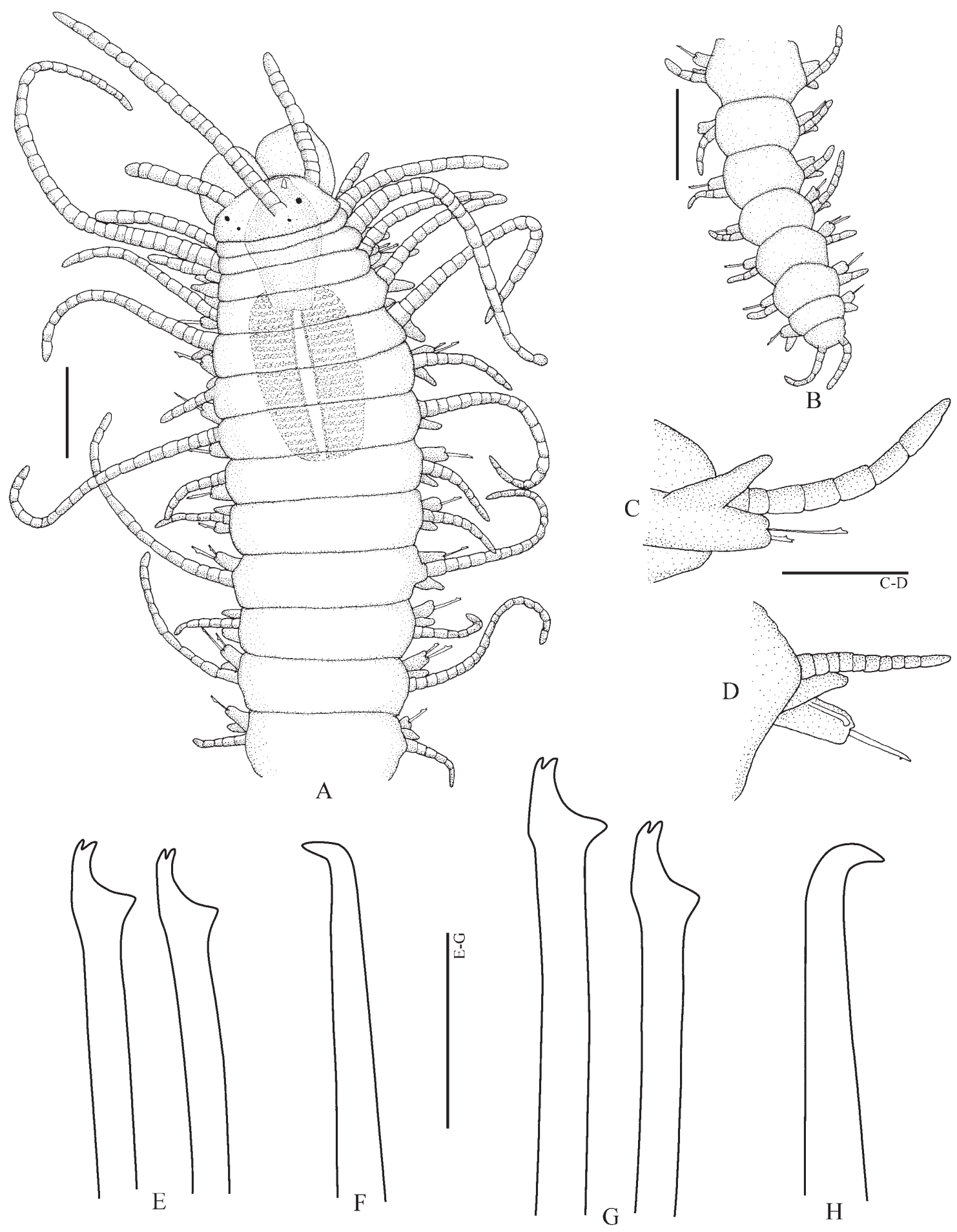

FIG. 11. - Hand-drawing of Haplosyllis gula. A, anterior end, dorsal view. B, posterior end, dorsal view. C, anterior parapodium, chaetiger 5. D, mid-body parapodium. E, anterior chaetae, chaetiger 3. F, anterior acicula, chaetiger 3. G, mid-body chaetae. H, mid-body acicula. Scale bars: A-B $(200 \mu \mathrm{m}), \mathrm{C}-\mathrm{D}(100 \mu \mathrm{m}), \mathrm{E}-\mathrm{H}(20 \mu \mathrm{m})$. INV-ANE 3465.

The chaetal and acicular shapes of $H$. chaetafusorata $\mathrm{n}$. sp. are very similar to those of an H. spongicola reported by Uebelacker (1984). However, this material must be checked to confirm that it corresponds to the species herein described.
The traces of fusion between the blade and shaft are also present in Haplosyllis loboi Paola, San Martín and Martin, 2006, but the species can be easily distinguished from $H$. chaetafusorata by the presence of long spines on the US of MF and between the MF and the apical teeth. 

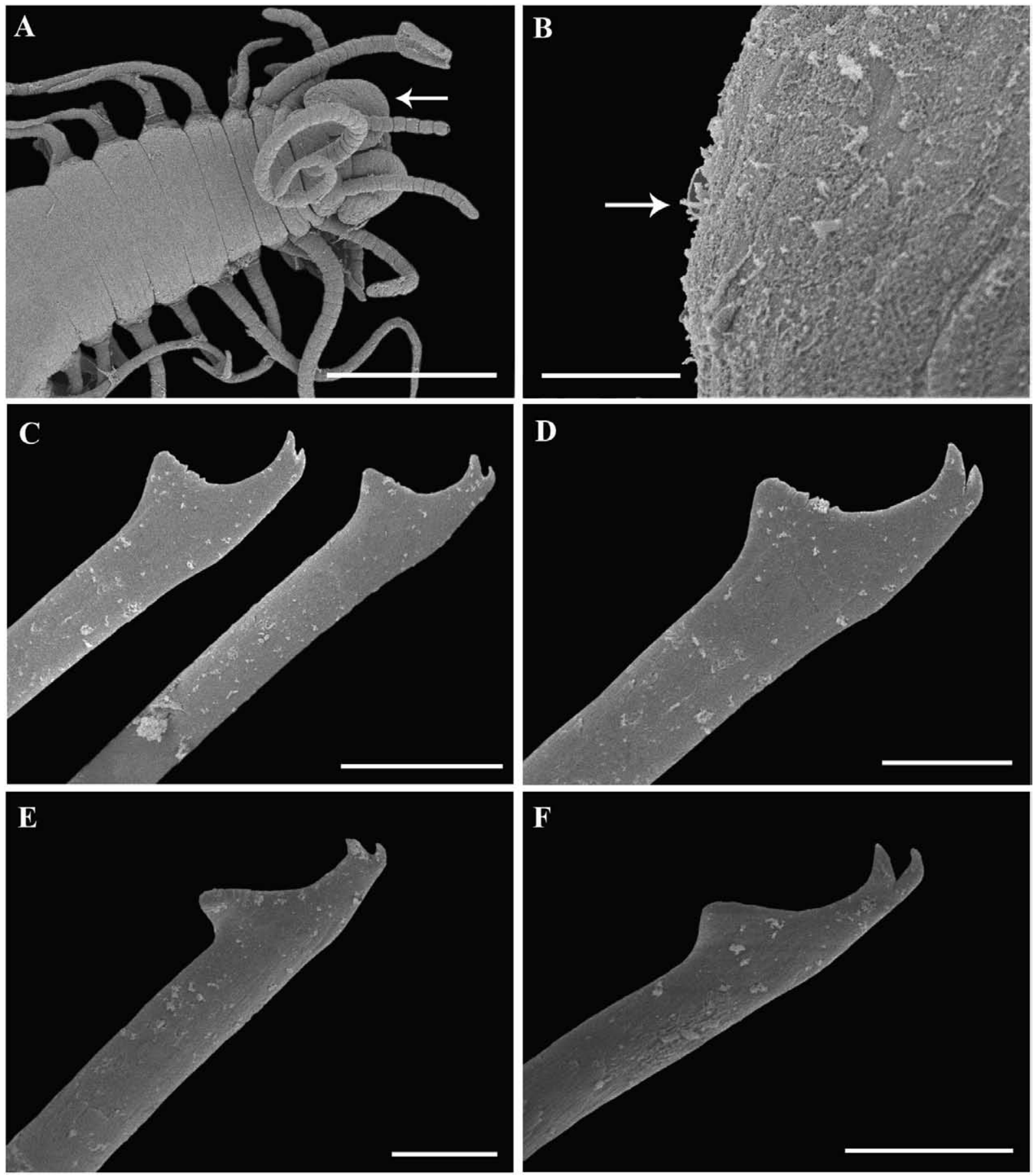

FIG. 12. - SEM micrographs of Haplosyllis gula. A, anterior end, dorsal view, arrow point on cilia. B, upper ventral side of palps, arrow points on cilia. C, mid-body chaetae. D, detail of long chaeta. E, posterior long chaeta. F, posterior short chaeta. Scale bars: A (300 $\mu \mathrm{m})$, B-C (10 $\mu \mathrm{m})$, D-F $(5 \mu \mathrm{m})$. INV-ANE 3465.

Haplosyllis gula Treadwell, 1918 (Figs. 11A-H, 12A-F)

Haplosyllis gula Treadwell, 1924: 11-12, pl. II. Figs. 19-23.-Hartman, 1956: 251.-Lattig and Martin 2009: 20, Figs. 13-14.

Examined material. Colombia, Santa Marta, Punta de Betín. $>100$ (plus 2 for SEM) specimens INV-ANE 3465; $>100$ specimens INVANE 3470: inside Neofibularia nolitangere, 6-8 m depth.
Comparative examined material. Barbados, Caribbean Sea. 11 types of H. gula, USNM 20327.

Description. Body translucent, slender, fragile, small, 3-4 mm length, about $0.3 \mathrm{~mm}$ wide excluding parapodia, with 26-31 segments. Anterior end wide, gradually thinner towards posterior end, with broad pharynx (Fig. 11A). Preserved specimens pale yellow. 
Prostomium subpentagonal, wider than longer, with two pairs of small red eyes in trapezoidal arrangement. Median antenna twice as long as lateral ones (17-37 and 7-13 articles, respectively); median antennae inserted on middle of prostomium, lateral one on anterior margin (Figs 11A, 12A). Palps long, broadly triangular, fused at their bases, with cilia on upperventral side making up the sensory organs (Fig. 12AB). Nuchal organs as lateral groups of cilia between prostomium and peristomium. Pharynx reddish-brown, broad, about $0.2 \mathrm{~mm}$ wide, reaching to proventricle as a funnel, $0.3 \mathrm{~mm}$ length, extending through about three segments, with large anterior tooth and crown of 10-11 soft papillae; inner ring of cilia and cilia of papillae not seen. Proventricle cylindrical, dark-brown, 0.3-0.4 mm long, about $0.2 \mathrm{~mm}$ wide, extending for 3-5 segments, with 21-30 muscle cell-rings (Fig. 11A). Peristomium well defined, slightly shorter than subsequent segments. Dorsal tentacular cirri longer than ventral one (7-19 and 3-7 articles, respectively). Dorsal cirri slender, slightly shorter at the tip, similar to antennae and tentacular cirri. First cirri longer than remaining ones, with 16-34 articles, second smaller (4-12 articles), third and fourth longer than second (8-17 and 15-24 articles, respectively), fifth short (5-9 articles), sixth long (15-25 articles). Subsequent cirri alternating between short (4-7 articles) and long (8-20 articles) (Fig. 11A); longest cirri exceed body width. Posterior cirri short (1-6 articles) (Fig. 11B). Ventral cirri triangular, anterior ones similar to or longer than parapodial lobe (Fig. 11C), gradually shorter toward posterior end (Fig. 11D). Chaetae bidentate, 2-4 per parapodia, all similar in shape, with short spines on US of MF. LMF similar to SW; MJP straight, long, apical teeth long, distal one slightly smaller than proximal tooth (Figs 11E, G. 12CF). Aciculae with $90^{\circ}$ curved tip (Fig. $11 \mathrm{~F}, \mathrm{H}$ ); two aciculae in anterior parapodia, one at mid-body and posterior end.

Distribution. Caribbean Sea, Barbados, Colombia. Florida (?), Bahamas (?).

Habitat. Some of the type specimens of H. gula were attached to the body wall of other polychaetes. Conversely, the Colombian population lived endosymbiotically inside its host sponge Neofibularia nolitangere (Duchassaing and Michelloti, 1864). About one milliard of specimens inhabited the sponge fragment examined, and the polychaete was not found in any of the other twenty sponges collected from Punta de Betín (Colombia). A Haplosyllis species was previously reported from N. nolitangere in the Caribbean as an underwater picture of the two partners (Humann, 1992). However, it is impossible to distinguish the polychaete identity.

It would be interesting to explore the host sponge along its range of distribution, in order to assess the geographical pattern of the association, as well as to define the degree of specificity. Future studies of living specimens will also be required to clarify whether the parasite-like behaviour reported for the types were the result of a stress reaction caused by forcing the worm to leave their host during sample collecting and handling or a normal phase of its life cycle (with the other polychaetes being temporary hosts), as discussed for the species of Haplosyllides, a similar sponge endosymbiotic syllid genus (Martin et al., 2009).

Remarks. Haplosyllis gula is characterized by its broad pharynx, long ventral cirri, and long MJP, and is reported for the first time for Colombian waters. The Colombian specimens had a less broad pharynx than that of types (Barbados). However, both populations agree in pharynx shape (reaching the proventricle as a funnel), cirri and chaetal shape. The broad pharynx of the types could be related to the fact that they were attached to the body wall or branchiae of other polychaetes.

Haplosyllis navasi $\mathrm{n} . \mathrm{sp}$. (Figs. 13A-H; 14A-F)

Type material. Colombia, Santa Marta, Punta de Betín: Holotype INV-ANE 3453, 130 Paratypes (plus two for SEM) INV-ANE 3454: inside Ircinia strobilina, 6-8 $\mathrm{m}$ depth.

Description. Body translucent, slender, fragile, small. Holotype $4 \mathrm{~mm}$ long, 0.25 wide for $24 \mathrm{seg}$ ments. Paratypes 3-4 mm long, for 17-24 segments, about $0.3 \mathrm{~mm}$ wide excluding parapodia (Figs 13A; 14A), pale yellow when preserved, with round, small, brown granules on dorsum and tentacular cirri, scarce in dorsal cirri. Prostomium subpentagonal, wider than longer, with two pairs of small red eyes in trapezoidal arrangement. Median antenna longer than lateral one (16-21 and 6-10 articles, respectively), inserted on middle of prostomium; lateral antennae on anterior margin (Figs 13A, 14B). Palps almost twice as long as prostomium, broadly triangular, fused at their bases, with cilia on ventral side making up the sensory organs. Nuchal organs as lateral groups of cilia between prostomium and peristomium. Pharynx orange, half as wide as proventricle, extending through 3-4 segments, with large anterior tooth and crown of soft papillae; inner ring of cilia and cilia of papillae not seen. Proventricle cylindrical, dark-brown, considerably broad, about $0.3 \mathrm{~mm}$ wide (same as body width), 0.3-0.5 mm long, extending through 2-3 segments, with 20-25 muscle cell-rings (Figs 13A, 14A-B). Peristomium well defined, slightly shorter than subsequent segments. Dorsal tentacular cirri twice as long as ventral ones (8-14 and 4-6 articles, respectively). Dorsal cirri slender, similar to antennae and tentacular cirri. First cirri longer than remaining ones (17-23 articles), second and third small (5-10 articles), fourth longer (11-19 articles), subsequent cirri equal in length, not exceeding body width (5-9 articles), gradually 


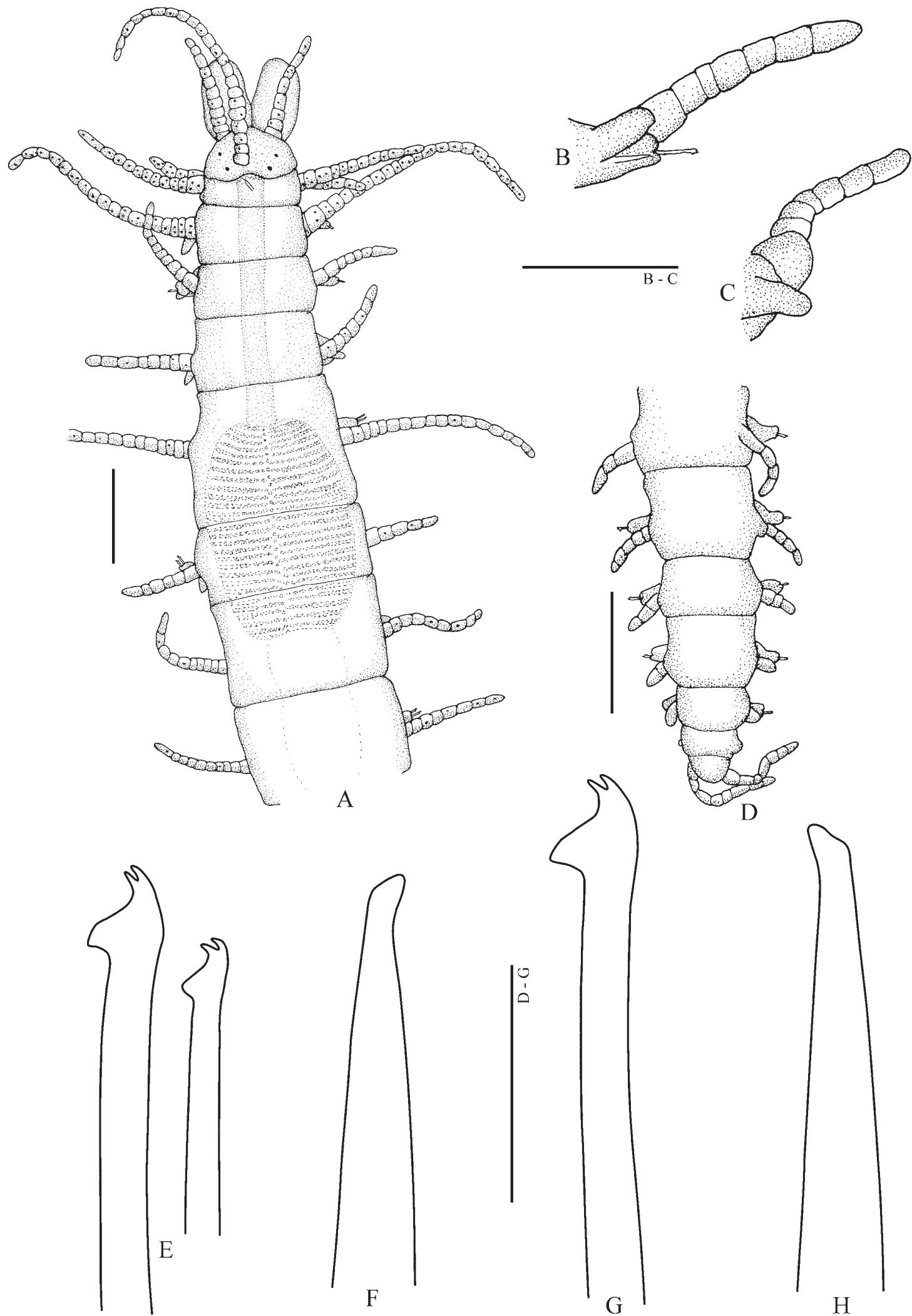

Fig. 13. - Hand-drawing of Haplosyllis navasi n. sp. A, anterior end, dorsal view. B, anterior parapodium, chaetiger 2. C, mid-body parapodium. D, posterior end, dorsal view. E, anterior chaetae, chaetiger 2. F, anterior acicula, chaetiger 2. G, mid-body chaeta. H, mid-body acicula. Scale bars: A, D $(200 \mu \mathrm{m}), \mathrm{B}-\mathrm{C}(100 \mu \mathrm{m}), \mathrm{E}-\mathrm{H}(20 \mu \mathrm{m})$. INV-ANE 3454. 

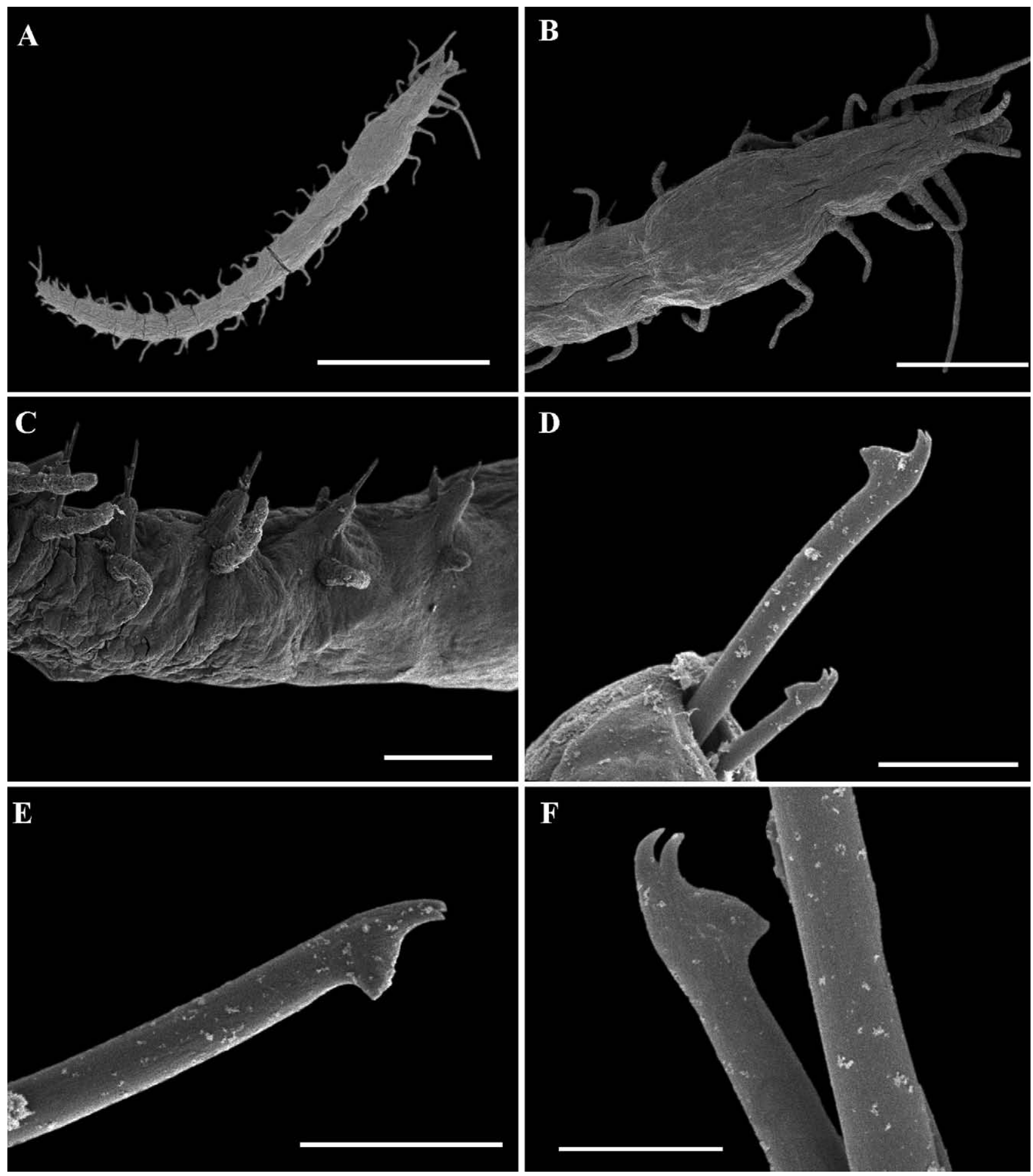

FIG. 14. - SEM micrographs of Haplosyllis navasi n. sp. A, whole body, dorsal view. B, anterior end, with broad proventricle. C, mid-body parapodia. D, posterior chaetae. E, mid-body large chaeta. F, mid-body, small chaeta. Scale bars: A (1 mm) B (300 $\mu \mathrm{m}), \mathrm{C}(100 \mu \mathrm{m}), \mathrm{D}-\mathrm{E}(10$ $u \mathrm{~m}), \mathrm{F}(5 \mu \mathrm{m})$. INV-ANE 3454.

decreasing in size toward posterior end (1-5 articles) (Figs 13D, 14C). Ventral cirri digitiform, similar to or shorter than parapodial lobes, gradually smaller to posterior end (Fig. 13B-C). Chaetae all bidentate, 2-3 per parapodia, similar throughout (Fig. 13E, G), with short spines on US of MF; mid-body parapodia of two different sizes; long chaetae with LMF similar than SW; MJP straight, short, apical teeth long, with wide angle (Figs 13G, 14D-E). Short chaetae with MJP short, curved (Fig. 14F). One acicula in all parapodia, small, with upwards directed curved tip (Fig. 13F, H). 


\section{Reproduction. Not known.}

Habitat. More than 100 specimens were found inside a fragment of Ircinia strobilina (Lamarck, 1816), collected at 6-8 m depth, together with 11 lumbrinerid, hesionid and cirratulid polychaetes, as well as two Branchiosyllis sp. As in the case of $H$. gula, $H$. navasi n. sp. only occurred in association with I. strobilina, among the 20 sponge species collected at Punta de Betín (Colombia), suggesting a species-specific endosymbiotic association. However, I. strobilina is widely distributed within the Caribbean and nearby regions, and future studies will be required to assess the range of distribution of the polychaete and the exact nature of the relationship.

\section{Distribution. Colombia, Santa Marta Bay.}

Etymology. The species name, Haplosyllis navasi, refers to an enthusiastic Colombian researcher Gabriel Navas, whose passion greatly helps to increase the knowledge on the marine biodiversity and his efforts helped to give continuity to the "Museo de Historia Natural Marina de Colombia" and the INVEMAR Taxonomy and Systematic group.

Remarks. Haplosyllis navasi n. sp. is characterized by its broad proventricle, mid-body dorsal cirri all similar in length, brown small granules throughout dorsum, and small acicula. The aciculae of $H$. navasi n. sp. are similar to those of $H$. aplysinicola n. sp. (Fig. 5A-D) but for comparison see remarks of corresponding species. $H$. navasi n. sp. can be easily identified from $H$. gula by the chaetal MJP distance, the acicular shape and especially the width ratio between pharynx and proventricle; from $H$. cephalata by its broad acicula and short mid-body cirri; and from $H$. chaetafusorata n. sp. and $H$. niphatesicola $\mathrm{n}$. sp. (see corresponding remarks for the distinctive details).

Haplosyllis navasi n. sp. resembles $H$. carmenbritoae from Canary Islands by its thin pharynx, but the latter differs in alternation of mid-body cirri, long spines on US of MF of anterior chaetae, and the proventricle width, not as broad as in Haplosyllis navasi n. sp.

\section{Haplosyllis niphatesicola $\mathrm{n} . \mathrm{sp}$.} (Figs. 15A-I, 16A-H, 17A-F)

Examined material. Colombia, Santa Marta, Punta de Betín. Holotype INV-ANE 3463. 200 Paratypes (plus 2 for SEM) INV-ANE 3464: from Niphates erecta, 6-8 m depth.

Additional examined material. Belize, 80 specimens (plus two for SEM) MNCN 16.01/13201, from a pink reef sponge collected on 27 December 1999 by E. Ballesteros, 15 m depth. Haplosyllis sp.: Colombia, Santa Marta. 8 specimens (plus two for SEM) INV-ANE 3466: collected inside $N$. digitalis, 6-8 m depth.

Description. Body translucent, slender, small sized. Holotype measures $4 \mathrm{~mm}$ long for 33 segments; Paratypes 3-5 mm long, with 26-37 segments, about
$0.3 \mathrm{~mm}$ wide excluding parapodia, wider at proventricle, gradually thinner towards posterior-end (Fig. 16A). Yellow pale when preserved, with round, dorsal granules throughout (Fig. 15A, B). Prostomium subpentagonal to oval, wider than longer, with two pairs of small red eyes in trapezoidal arrangement. Median antenna longer than lateral ones (15-23 and 9-15 articles, respectively), inserted on middle of prostomium, lateral one inserted on anterior margin (Fig. 15A). Palps long, broadly triangular, fused at their bases, separated all along their length, with cilia on ventral upper side making up the sensory organs (Fig. 16C). Nuchal organs as lateral groups of cilia between prostomium and peristomium (Fig. 17B). Pharynx orange, as wide as proventricle, extending through 3-6 segments; with large anterior tooth, crown of about $11 \mathrm{soft}$ papillae and inner ring of cilia (Fig. 16B); papillae with abundant cilia on ventral side (Fig. 16D). Proventricle cylindrical, dark-brown, 0.3-0.6 mm wide, extending through 5-8 segments, with 32-42 muscle cell-rings (Fig. 15A). Peristomium well defined, shorter than subsequent segments. Dorsal tentacular cirri longer than ventral one (13-18 and 6-15 articles, respectively). Dorsal cirri slender, similar to antennae and tentacular cirri. First cirri longer than remaining ones (18-28 articles), second, third and fourth gradually longer (6-13, 9-16 and 11-18 articles, respectively); fifth short (4-11 articles), sixth long (10-14 articles) (Figs. 15A, 17A). Subsequent cirri alternating with long (5-9 articles) and short (1-4 articles) (Figs. 15A, 16E); longest cirri do not exceed body width; posterior cirri short (1-7 articles) (Fig. 15B). Ventral cirri digitiform, anterior ones similar to or longer than parapodial lobe; gradually shorter to posterior end (Fig. 15C-D). Chaetae all bidentate, one in anterior segments, small, with spines on US of MF (Figs 15E, 16F, 17C); 1-3 in mid-body and posterior parapodia, with MF longer than SW and with pointed tip; MJP straight, long; apical teeth short, distal tooth slightly smaller than proximal one; narrow angle between teeth (Figs 15H, 16G-H, 17F). Two aciculae in anterior parapodia, one straight (Fig. 15F), the other with upwards directed curved tip (Fig. 15G). Single acicula (rarely two) in mid-body and posterior parapodia, broader than chaeta, with upwards directed curved tip (Fig. 15 I). Pigidium with two long cirri (611 articles) (Fig. 15B).

Reproduction. A few Belize specimens showed traces of stolonization, with swimming chaetae in some posterior segments (Fig. 17D-E). Though no parapodial ocular spots were observed, the phase was too preliminary to distinguish the stolon type.

Habitat. More than 2000 Haplosyllis niphatesicola n. sp. were found inside a small fragment of Niphates erecta Duchassaing and Michelotti, 1864, between 6-8 m depth. Eight Haplosyllis specimens also found inside $N$. digitalis (Lamarck, 1814) are similar to $H$. niphatesicola $\mathrm{n}$. sp., but their taxonomic position must 

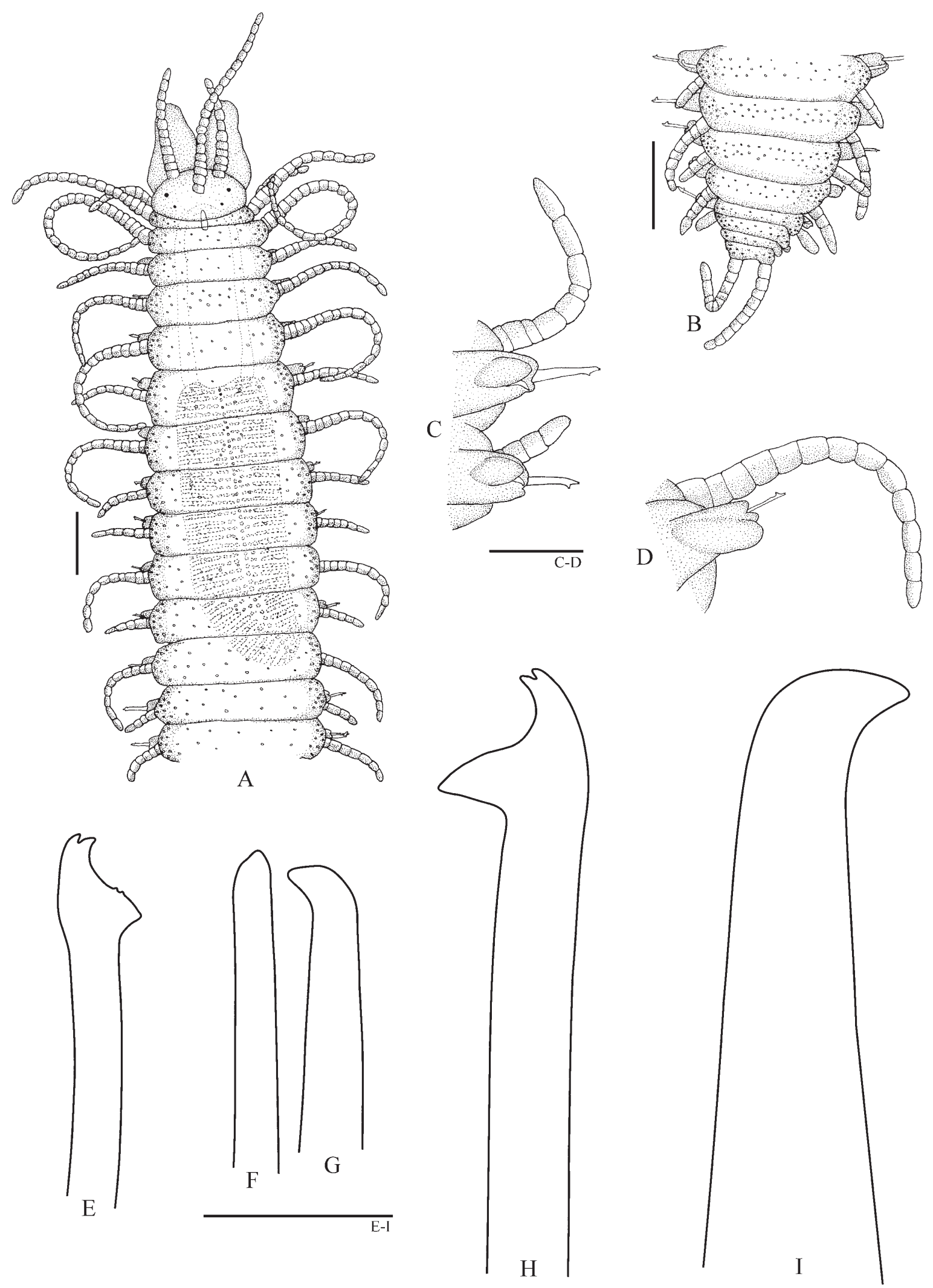

FIG. 15. - Hand-drawing of Haplosyllis niphatesicola n. sp. A, anterior end, dorsal view. B, posterior end, dorsal view. C, mid-body parapodia, five post-proventricular segments. D-G: Chaetiger 3. D, parapodium. E, chaeta. F, straight acicula. G, acicula with curved tip. H-I: Chaetiger 13. H, mid-body chaeta. I, mid-body acicula. Scale bars: A-B $(200 \mu \mathrm{m}), \mathrm{C}-\mathrm{D}(100 \mu \mathrm{m})$, E-I $(20 \mu \mathrm{m})$. INV-ANE 3464. 

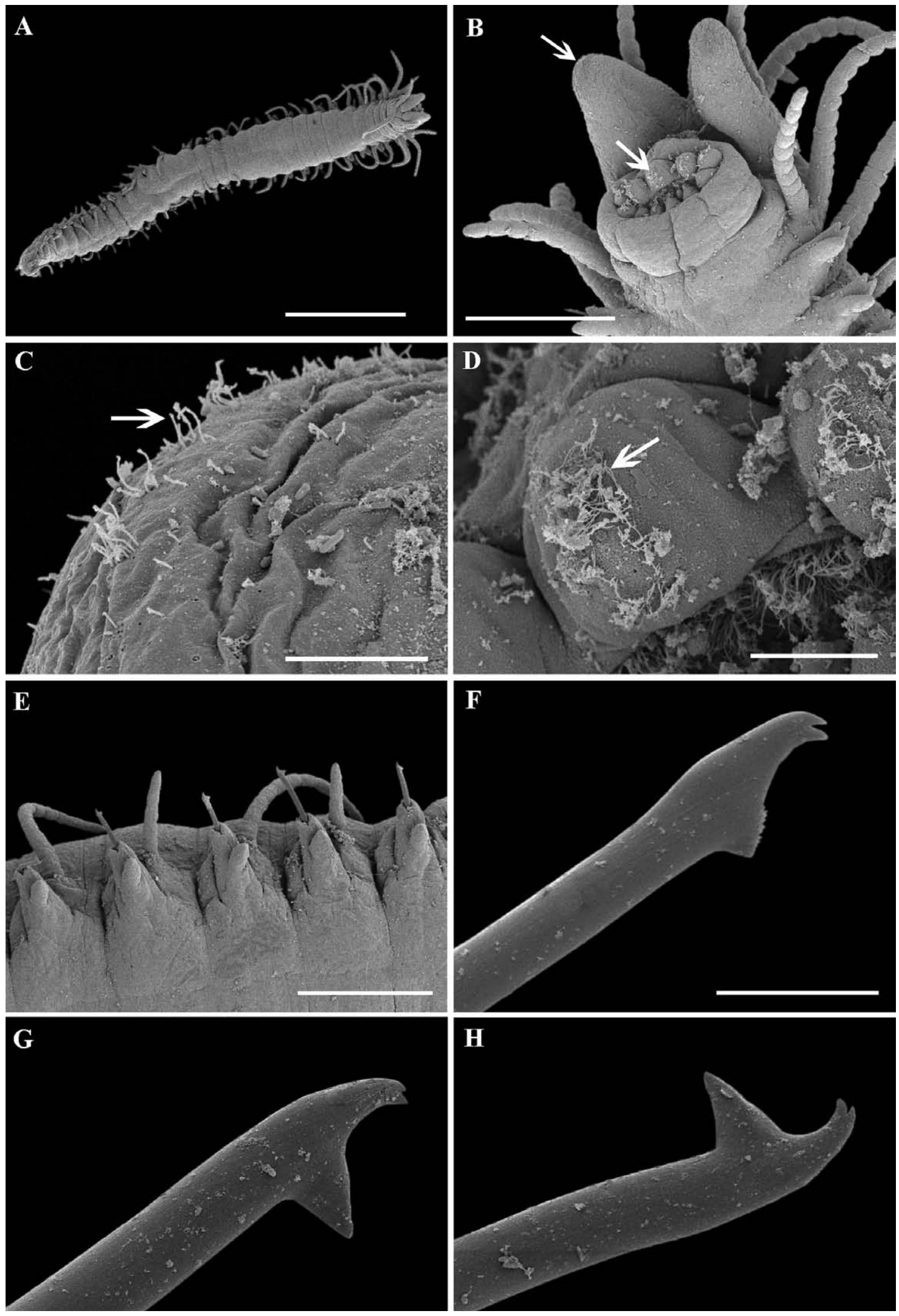

FIG. 16. - SEM micrographs of Haplosyllis niphatesicola $\mathrm{n}$. sp. A, whole body, lateral view. B, anterior end, ventral view, arrows point on cilia on palps and pharyngeal papillae. C, detail of cilia on upper side of palps, indicated by arrow. D, detail of cilia on ventral side of pharyngeal papillae, indicated by arrow. E, mid-body parapodia with cirri alternating long and short. F, anterior chaetae, chaetiger 4 . G, mid-body chaeta. $\mathrm{H}$, posterior chaeta. Scale bars: A $(1 \mathrm{~mm})$; B, E $(200 \mu \mathrm{m})$; C, F $(10 \mu \mathrm{m})$; D, G-H $(20 \mu \mathrm{m})$. INV-ANE 3464 

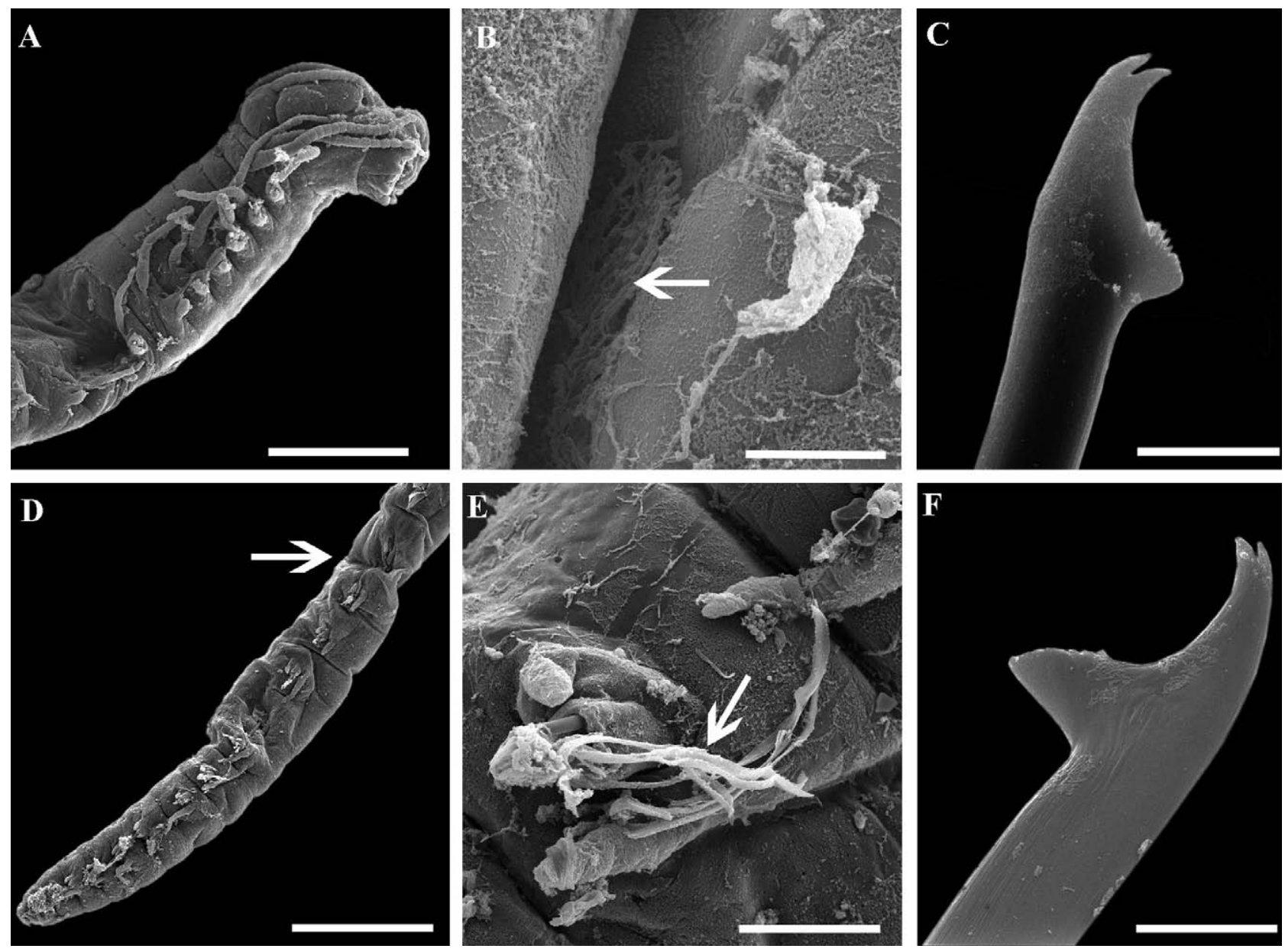

FIG. 17. - SEM micrographs of Haplosyllis niphatesicola n. sp. from Belize. A, anterior end, lateral view. B, detail of nuchal organs, arrow point on cilia. C, anterior chaeta. D, posterior end of a stolonizing specimen, arrow points at the beginning of stolon. E, detail of parapodium of the stolonized region, arrow points to swimming chaetae. F, posterior chaetae. Scale bars: A $(400 \mu \mathrm{m}), \mathrm{B}(12 \mu \mathrm{m}), \mathrm{C}(6 \mu \mathrm{m}), \mathrm{D}(500 \mu \mathrm{m})$, $\mathrm{E}(50 \mu \mathrm{m}), \mathrm{F}(8.6 \mu \mathrm{m}) . \mathrm{MNCN} 16.01113201$.

be confirmed (see remarks). The specimens from Belize were collected in a non-identified pink coral-reef sponge at $15 \mathrm{~m}$ depth and their identity must be checked prior to confirming the host-symbiont relationship as genus-specific.

\section{Distribution. Caribbean Sea: Belize, Colombia.}

Etymology. Haplosyllis niphatesicola $\mathrm{n}$. sp. refers to the host sponge in which the Colombian specimens were found, Nyphates erecta.

Remarks. Haplosyllis niphatesicola n. sp. is characterized by the mid-body cirri alternating with long and short, round dorsal granules throughout and broad posterior acicula. $H$. niphatesicola $\mathrm{n}$. sp. resembles $H$. cephalata in having similar broad acicula (Fig. 8E, G) but differ in its longer mid-body cirri. H. aplysinicola $\mathrm{n}$. sp. and $H$. chaetafusorata n. sp. are also similar to $H$. niphatesicola $\mathrm{n}$. sp. in body shape and alternation of mid-body cirri. However, the former has small duck-tip shaped aciculae and broad chaetae with short MJP, and the latter lacks dorsal granules, the chaetae have traces of fusion between blade and shaft and some aciculae are straight (Fig. 8B, F). In contrast, $H$. navasi $\mathrm{n}$. sp. may be easily distinguished from $H$. niphatesicola $\mathrm{n}$. sp. because it has all midbody cirri similar in size, a different pharynx width and smaller aciculae.

The eight specimens found inside Niphates digitalis resemble $H$. niphatesicola $\mathrm{n}$. sp. in having chaetae with long and pointed MF (Fig. 8C-D) and abundant dorsal granules. However, their bodies are broader and longer (7-8 mm long, with 50-64 segments), and have two broad aciculae (instead of only one) (Fig. 8G-H) that also resemble those of Haplosyllis chaetafusorata n. sp. (which lacks dorsal granules and has traces of fusion between blade and shaft, Fig. 8B, F). The number of specimens, however, is not sufficient to clarify their taxonomic position. They could either be a different new species, or represent larger individuals of $H$. niphatesicola $\mathrm{n}$. sp. pointing to a morphological variability slightly higher that herein described. 


\section{DISCCUSION}

The species of Haplosyllis are commonly found in association with sponges and gorgonians (Lattig and Martin, 2009) but the real nature of their relationships is almost unknown (Martin and Britayev, 1998). Among the 32 species known to date, only 16 have been specifically reported in association with a host (or a group of hosts) and in most cases they correspond to descriptions made during the last decade (Table 1).

The Haplosyllis species known to be associated with gorgonians seem to be less diverse than those associated with sponges, and have been recently reviewed by Martin et al. (2002). They are known only from temperate and subtropical regions, and have been considered as parasitic, because they induce changes in the morphology of their host gorgonians and seemed to feed by stealing food from the host polyps (i.e. kleptoparasitism) (Martin et al. 2002). From a morphological point of view, Haplosyllis chamaeleon and $H$. villogorgicola more closely resemble the species of Alcyonosyllis, particularly in chaetal shape and reproductive cycle (Martin et al. 2002; Glasby and Watson, 2001), while $H$. anthogorgicola seemed to be closer to some sponge associates species, such as $H$. basticola (Sardá et al. 2002; Martin et al. 2002).

The current knowledge on the ecological significance of these relationships involving sponge-associated species of Haplosyllis was extensively discussed in López et al. (2001). The authors postulated the possible existence of two different life strategies: specialized sponge predators (for the large worms from temperate regions) and strict endosymbionts (for the smaller tropical worms). The latter were defined as parasites or "good" parasites, as all phases of their life cycle occur inside the hosts, often all year round and without disturbing the growth and reproduction of the sponges (López et al., 2001). However, these authors already indicated that further studies would be required to clarify "the exact nature of the host/symbiont relationships, as well as the host specificity of the different morphotypes" of what was assumed to be a speciescomplex. The taxonomic consequences of the second part of this statement are discussed at the end of this section.

Tropical endosymbiotic Haplosyllis are commonly found in very high densities inside their host (Bacescu, 1971; Magnino and Gaino, 1998; López et al., 2001; Lattig et al., 2010a). They are living inside the aquiferous canals of the sponges, feeding on the host tissues, as demonstrated on the basis of direct histological observations, as well as through the coincidence of the absorption spectra of both host tissues and symbiont gut contents (Tsurumi and Reiswig, 1997; Magnino et al., 1999; Martin and Britayev 1998). This supported a possible parasitic behaviour according to López et al. (2001). In contrast, such a trophic relationship was refused by Sardá et al. (2002) based on the absence of bastadins (a typical compound of the sponge Ianthella basta) in its associated specimens of Haplosyllis basticola. Taking into account the previously existing information, however, the second hypothesis proposed by Sardá et al. (2002), i.e. possible damage to the bastadins occurring during the analytical procedures, appears to be more reliable.

Surprisingly, both the high densities and "parasitic" behaviour seemed not to be associated with any significant damage to the hosts, which were able to survive and maintain their symbiotic Haplosyllis populations even in very adverse conditions (López et al., 2001 and

TABLE 1. - List of the 16 species of Haplosyllis with known hosts, arranged according to geographical distribution.

\begin{tabular}{|c|c|c|c|}
\hline Species of Haplosyllis & Species & Family & Taxa \\
\hline \multicolumn{4}{|l|}{ INDO-PACIFIC } \\
\hline Haplosyllis anthogorgicola & Anthogorgia bocki & Acanthogorgiidae & Gorgoniacea \\
\hline Haplosyllis basticola & $\begin{array}{l}\text { Ianthella basta } \\
\text { Anomoianthella lamella }\end{array}$ & Ianthellidae & Porifera \\
\hline \multirow{3}{*}{$\begin{array}{l}\text { Haplosyllis ingensicola } \\
\text { Haplosyllis nicoleae }\end{array}$} & Acanthostrongylophora ingens & Petrosiidae & Porifera \\
\hline & $\begin{array}{l}\text { Clathria (Thalysias) reinwardti } \\
\text { Biemna triraphis }\end{array}$ & Microcionidae & Porifera \\
\hline & Melophlus sarassinorum & $\begin{array}{l}\text { Desmacellidae } \\
\text { Ancorinidae }\end{array}$ & \\
\hline \multirow{2}{*}{$\begin{array}{l}\text { MEDITERRANEAN AND ATLANTIC } \\
\text { Haplosyllis chamaeleon }\end{array}$} & & & \\
\hline & $\begin{array}{l}\text { Paramuricea clavata } \\
\text { Paramuricea grayii }\end{array}$ & Plexauridae & Gorgoniacea \\
\hline \multirow{2}{*}{\multicolumn{4}{|c|}{ INDIAN OCEAN and RED SEA }} \\
\hline & & & \\
\hline Haplosyllis eldagainoae & Theonella swinhoei & Theonellidae & Porifera \\
\hline Haplosyllis giuseppemagninoi & Liosina paradoxa & Dyctionellidae & Porifera \\
\hline \multicolumn{4}{|l|}{ CARIBBEAN SEA } \\
\hline Haplosyllis agelas & Agelas dispar & Agelasidae & Porifera \\
\hline Haplosyllis cephalata & Ircinia campana & Irciniidae & Porifera \\
\hline Haplosyllis gula & Neofibularia nolitangere & Desmacellidae & Porifera \\
\hline Haplosyllis navasi $\mathrm{n} . \mathrm{sp}$. & Ircinia strobilina & Irciniidae & Porifera \\
\hline Haplosyllis aplysinicola $\mathrm{n}$. sp. & Aplysina spp. & Aplysinidae & Porifera \\
\hline Haplosyllis chaetafusorata n. sp. & Verongula rigida & Aplysinidae & Porifera \\
\hline \multirow[t]{2}{*}{ Haplosyllis niphatesicola $\mathrm{n}$. sp. } & Niphates erecta & Niphatidae & Porifera \\
\hline & Niphates digitalis & & \\
\hline
\end{tabular}


references herein). The most sticking example dealt with upper coral-reef sponges. Despite the sponge hosts loosed their photosynthetic symbionts when artificially transferred to lower (i.e. darker) sectors of the reef, they survived in perfect conditions, keeping the respective endosymbiotic populations of Haplosyllis active and numerous (Maldonado and Young, 1998a). This leads us to postulate that the association between Haplosyllis and their host sponges may benefit both partners, so that it may be mutualistic rather than parasitic.

Certainly, there are some obvious benefits for the symbiotic worms, such as protection and unrestricted food availability. Conversely, the benefits of keeping thousands of hungry worms inside are apparently not so evident for the host sponges. Sardá et al. (2002) proposed that worms may feed on particles larger than $5 \mu \mathrm{m}$ inside the aquiferous channels of the sponges, which are not very efficient in capturing these large particles and must spend energy to expel them out. By considering that the worm populations could persist by feeding upon these particles, they proposed that the sponge could benefit from feeding on the digested material excreted by the worms. Consequently, they already postulated a positive reciprocal relationship for the partnership. However, the pellets excreted by the worms are larger than $5 \mu \mathrm{m}$, so that they cannot be directly ingested by the sponge. Conversely, we suggest that it could be possible for the host sponges to feed on the bacteria associated with these faecal matters, which could be a real trophic benefit for them.

In turn, sponges are surprising organisms having high plasticity and regeneration capacities, e.g. reaching up to 2900 times the normal growth rate after tissue damage (Ayling, 1983), as well as a high telomerase activity (Koziol et al., 1998). This indicates their potential for relatively rapid cell proliferation rates during the whole adult life, though they did not show a continuous increase in individual biomass (De Goeij et al. 2009). Coral-reef sponges inhabit oligotrophic waters, forcing them to efficiently filter large volumes of water. In these conditions, high cell turnovers may prevent permanent damage to the sponge tissues by environmental stress (De Goeij et al. 2009). As reported for other species, the reef cavity sponge Halisarca caerulea maintains both a stable body mass and a healthy food uptake system by constantly renewing its filter tissues. The exceeding cells are shed out of the sponge body, generating large amounts of detritus daily that may be consumed by other reef residents (De Goeij et al. 2009). The tropical sponges hosting Haplosyllis populations must deal with the same environmental conditions, so they are submitted to similar constraints. Taking this into account, we postulate that the continuous grazing of the symbiotic Haplosyllis on the host tissues may be a mechanism having a significance for these sponges similar to cell shedding in $H$. caerulea, the main difference being that the benefited consumers are inside instead of outside. This may certainly be an additional reason rein- forcing the mutualistic character of these associations and also helping to explain their ubiquitous presence in tropical waters.

Further additional support to the existence of benefits for the host sponges was highlighted by Martin et al. (2009, and references herein), who reported on several direct observations of endosymbiotic Haplosyllis being able to defend their host from the attacks of spongivorous nudibranch species of the genus Hypselodoris. This behaviour has been reported as being typically associated with territorial symbiotic polychaetes (Martin and Britayev, 1998) and seems to be exactly the same as that of the polynoid Arctonoe vitatta defending its host limpet from the attacks of predator starfish (see the spectacular film by Williams, 2009).

Furthermore, the association may play a role in the energy transfer to higher levels of the reef's trophic web, as suggested for cell shedding in Halisarca caerulea (De Goeij et al. 2009). Sardá et al. (2002) paid attention to the frequent presence of the small goby fish, Pleurosicya elongata, living on the surface of Iantella basta, one of the typical hosts of Haplosyllis basticola. These authors suggested that the worms, occasionally going out of the sponge and sometimes expelling reproductive stolons, may also serve as a good food resource for the fish. In fact, this hypothesis proved to be not only possible, but much more common than expected. In five of six species of the strict sponge-symbiotic species of the small gobiid fish of the genus Elacatinus, the main (if not the only) preys found inside the gut were specimens of Haplosyllis (Randall and Lobel, 2009). The most astonishing characteristic of this finding is not that the gobiids feed on the worms sharing the same host, but the co-evolutive implications of the behavioural strategy used to get their preys. What they do is a repeated biting on the sponge surface to simulate the attack of a sponge predator, which consequently triggers the host-defence behaviour of the worms. As soon as the "brave" Haplosyllis protrude out of the sponge surface to defend the host, they are simply "collected" by the fish (L. Harris, personal communication). Indeed, however excellent a strategy adopted in nature may be, there is always somebody adapted to get benefits from it (very often with unexpected negative consequences for the initial "clever" partners).

In conclusion, the recent efforts dedicated to clarifying the taxonomy of the so-called Haplosyllis spongicola species-complex have increased the species diversity of the whole genus by three, from 12 in Licher (1999) to 32, including the new species described herein as well as two additional ones from the Indian Ocean and Red Sea (Lattig and Martin, 2011). In addition, the distributional ranges of the different species are restricted to relatively well-defined biogeographical regions, and the respective associations revealed a high degree of specificity. However, this is not the most significant result, but the fact that this series of studies establish a solid basis for further contributions reveal the real diversity of the genus, which may be even as rich as its close relative Syllis, with more than 
120 species known to date (San Martín, 2003). This will also help to prevent the persistence of misleading results, such as that in the recent inventory of spongeassociated macrofaunal assemblages from SE USA coasts, where all Haplosyllis from the different sponge species were reported as $H$. spongicola (Fiore and Cox Jutte, 2010). In the light of our results, these authors are certainly not dealing with this species, but with several different ones, some of them likely undescribed.

Despite the increasing amount of taxonomic information, the knowledge on other aspects in which the species of Haplosyllis are involved is still very scarce. Thus, we would also like to encourage other authors to contribute by studying non-taxonomic topics such as reproductive strategies (which could be very helpful in clarifying the phylogenetic relationships within the species of the genus) and, obviously, the ecological features of the symbiotic relationships. As postulated for the association between the deep-sea polynoid Branchipolynoe seepensis and its host mussels (Bathymodiolus spp.) in hydrothermal vent ecosystems (Britayev et al. 2007), the high diversity of the genus and the characteristics of the symbiosis between Haplosyllis and its host sponges strongly supports the hypothesis that this type of relationship may play a highly relevant functional role in tropical ecosystems and, particularly, in coral reefs.

\section{ACKNOWLEDGEMENTS}

We are grateful to the Instituto de Investigaciones Marinas y Costeras (INVEMAR) for the loan of the Colombian material, collected with the help of S. Zea (Universidad Nacional de Colombia), P. Flórez and G. Navas (INVEMAR). Miguel Martelo (INVEMAR) provided facilities for laboratory use and P. Flórez checked the museum numbers. The material from the Bahamas was loaned by M. Maldonado (CEABCSIC); that from Barbados by H.M. Reiswig (Redpath Museum at McGill University); that from Belize by E. Ballesteros (CEAB-CSIC); and that from Venezuela by D. Bone (Universidad Simón Bolivar). We would like to thank K. Fauchald and L. Ward (USNM) and E. Lazo-Wasem (YPM) for loan of type material, and L. Harris (Natural History Museum of Los Angeles County) for kindly sharing with us his highly valuable observations on the behaviour of Haplosyllis and Elacatinus living symbiontically with coral reef-sponges. The SEM images were made with help of J.M. Fortuño from the SEM service of ICM-CSIC. This is a contribution of P. Lattig to INVEMAR (No. 1072) and of D. Martin to the Consolidated Research Group 2009SRG665 of the Generalitat de Catalunya.

\section{REFERENCES}

Aguado, M.T., G. San Martín and E. Nishi. - 2006. Two new species of Syllidae (Polychaeta) from Japan. In: R. Sarda, G. San Martín, E. López, D. Martin and D. George (eds.), Sci. Mar., 70S3: 9-16.

Allen, E.J. - 1923. Regeneration and Reproduction of the Syllid
Procerastea Philos Trans. R. Soc Lond B 211: 131-177.

Ayling, A.L. - 1983. Growth and regeneration rates in thinly encrusting demospongiae from temperate waters. Biol. Bull., 165: 343-352.

Bacescu, M. - 1971. Les Spongiaires: un des plus intéressants biotopes benthiques marins. Rapp CIE Mer Méd., 20: 239-241.

Boilly, B. and N. Thibaut. - 1974. Étude histologique de la régénération pharyngienne de Syllis gracilis Grube (Annélide, Polychète) Can. J. Zool., 52: 169-177.

Britayev, T.A., D. Martin, E.M. Krylova, R. von Cosel and E.S. Aksiuk. - 2007. Life-history traits of the symbiotic scale-worm Branchipolynoe seepensis and its relationships with host mussels of the genus Bathymodiolus from hydrothermal vents. Mar. Ecol.: Evol. Perspec., 28(1): 36-48.

De Goeij, J.M., A. De Kluijver, F.C. Van Duyl, J. Vacelet, R.H. Wijffels, A.F.P.M. De Goeij, J.P.M. Cleutjens and B. Schutte. -2009 . Cell kinetics of the marine sponge Halisarca caerulea reveal rapid cell turnover and shedding. J. Exp. Biol., 212: 3892-3900.

Fiore, C.L. and P.C. Jutte. - 2010. Characterization of macrofaunal assemblages associated with sponges and tunicates collected off the southeastern United States. Invertebr. Biol., 129: 105-120.

Genzano, G.N. and G. San Martín. - 2002. Association between the polychaete Procerastea halleziana (Polychaeta: Syllidae: Autolytinae) and the hydroid Tubularia crocea (Cnidaria: Hydrozoa) from the Mar del Plata intertidal zone, Argentina. Cah. Biol. Mar., 43: 165-170.

Glasby, C.J. and C. Watson. - 2001. A new genus and species of Syllidae (Annelida: Polychaeta) commensal with octocorals. The Beagle, 17: 43-51.

Hartman, O. - 1956. Polychaetous Annelids erected by Treadwell, 1891 to 1948 , together with a brief chronology. Bull. Am. Mus. Nat. Hist., 109: 239-310.

Humann, P. - 1992. Reef creature identification. Florida, Caribbean, Bahamas. Orlando: Vaughan Press.

Imajima, M. - 1966. The Syllidae (Polychateous Annelids) from Japan (IV) Syllinae (1). Publ. Seto Mar. Biol. Lab., XIV: 218-252.

Imajima, M. and O. Hartman. - 1964. The Polychaetous annelids of Japan, Part I. Allan Hancock Found. Publ. Occas. Pap., 26: $1-452$.

Koziol, C., R. Borojevic, R. Steffen, and W.E.G. Müller. - 1998. Sponges (Porifera) model systems to study the shift from immortal to senescent somatic cells: the telomerase activity in somatic cells. Mech. Ageing Dev. 100: 107-120.

Kudenov, J.D. and L.H. Harris. - 1995. Family Syllidae Grube, 1850. In: Blake, J.A., B. Hilbig, and P.H. Scott (eds.) Taxonomic atlas of the benthic fauna of the Santa Maria Basin and western Santa Barbara Channel, vol. 5, part 2. Santa Barbara Museum of Natural History, Santa Barbara, California, pp. 1-99.

Lattig, P. and D. Martin. - 2009. A taxonomic revision of the genus Haplosyllis Langerhans, 1887 (Polychaeta: Syllidae: Syllinae). Zootaxa, 2220: 1-40.

Lattig, P. and D. Martin. - 2011. Two new endosymbiotic species of Haplosyllis (Polychaeta: Syllidae) from the Indian Ocean and Red Sea, with new data on $H$. djiboutiensis from the Persian Gulf. Italian J. Zool. DOI: 10.1080/11250003.2011.569373

Lattig, P., D. Martin and M.T. Aguado. - 2010a. Four new species of Haplosyllis (Polychaeta: Syllidae: Syllinae) from Indonesia. J. Mar. Biol. Ass. U.K., 90(4): 789-798.

Lattig, P., D. Martin and G. San Martín. - 2010b. Syllinae (Syllidae: Polychaeta) from Australia. Part 4. The genus Haplosyllis Langerhans, 1879. Zootaxa, 2552: 1-36.

Lattig, P., G. San Martín and D. Martin. - 2007. Taxonomic and morphometric analyses of the Haplosyllis spongicola complex (Polychaeta: Syllidae: Syllinae) from Spanish seas, with re-description of the type species and descriptions of two new species. Sci. Mar., 71: 551-570.

Langerhans, P. - 1879. Die Wurmfauna von Madeira. Z. Wissens. Zool., 32: 513-592.

Langhammer, H. - 1928. Teilungs, und regenerations-vorgänge bei Procerastea halleziana und ihre Beziehungen zu der Stolonization von Autolytus prolifer. Wiss. Meeresunter., Abt. Hegoloand, 17: 1-44.

Licher, F. - 1999. Revision der Gattung Typosyllis Langerhans, 1879 (Polychaeta: Syllidae). Morphologie, Taxonomie und Phylogenie. Abh. Sencken. Natfors. Ges., 551: 1-336.

López, E., T.A. Britayev, D. Martin and G. San Martín. - 2001. New 
symbiotic associations involving Syllidae (Annelida: Polychaeta), with some taxonomic and biological remarks on Pionosyllis magnifica and Syllis cf. armillaris. J. Mar. Biol. Ass. U.K., 81(3): 399-409.

Magnino, G. and E. Gaino - 1998. Haplosyllis spongicola (Grube) (Polychaeta, Syllidae) associated with two species of sponges form East Africa (Tanzania, Indian Ocean). Mar. Ecol., 19: 77-87.

Magnino, G., A. Sarà, T. Lancioni and E. Gaino. - 1999. Endobionts of coral reef sponge Theonella swinhoei (Porifera, Demospongiae). Invertebr. Biol., 118: 213-220.

Maldonado, M. and C.M. Young. - 1998a. Limits on the bathymetric distribution of Keratose sponges: a field test in deep water. Mar. Ecol. Prog. Ser., 174: 123-139.

Maldonado, M. and C.M. Young. - 1998b. Reevaluation of the stalked Aplysinid sponges, with description of a new species from the upper Bahamian slope. Bull. Mar. Sci., 63: 417-426.

Martin, D. and T.A. Britayev. - 1998. Symbiotic Polychaetes: Review of known species. Oceanogr. Mar. Biol. Annual Rev., 36: 217-340.

Martin, D., J. Núñez, R. Riera and J. Gil. - 2002. On the associations between Haplosyllis (Polychaeta, Syllidae) and gorgonians (Cnidaria, Octocorallaria), with the description of a new species. Biol. J. Linn. Soc., 77: 455-477.

Martin, D., T.A. Britayev, G. San Martín and J. Gil. - 2003. Interpopulation variability and character description in the spongeassociated Haplosyllis spongicola complex (Polychaeta: Syllidae). Hydrobiologia, 496: 145-162.

Martin, D., M.T. Aguado and T.A. Britayev. -2009 . Review of the symbiotic genus Haplosyllides (Polychaeta: Syllidae), with a description of a new species. Zool. Sci., 26(9): 646-655.

Okada, Y.K. - 1929. Regeneration and fragmentation in the syllidean polychaetes (Studies on the Syllidae). Z. Wiss. Biol., Abtlg. $D, 115: 542-600$.

Paola, A., G. San Martín and D. Martin. - 2006. A new species of Haplosyllis Langerhans, 1879 (Annelida: Polychaeta: Syllidae:
Syllinae) from Argentina. Proc. Biol. Soc. Wash., 119: 346-354. Randall, J.E. and P.S. Lobel. - 2009. A literature review of the sponge-dwelling gobiid fishes of the genus Elacatinus from the western Atlantic, with description of two new Caribbean species. Zootaxa, 2133: 1-19.

Reiswig, H.M. - 1973. Population dynamics of Three Jamaican Demospongiae. Bull. Mar. Sci., 23: 191-226.

San Martín, G. - 2003. Annelida, Polychaeta II: Syllidade. In M.A. Ramos, J. Alba, X. Bellés, J. Gosálbez, A. Guerra, E. Macpherson, J. Serrano and J. Templado (eds.), Fauna Iberica. Vol. 21, pp. 1-554. Madrid: CSIC.

Sardá, R. C. Avila and V.J. Paul. - 2002. An association between a syllid polychaete, Haplosyllis basticola $\mathrm{n}$. sp., and the sponge Ianthela basta. Micronesica, 34: 165-175.

Treadwell, A.L. - 1924. Reports on certain Invertebrates and fishes of the Barbados-Antigua Expedition from the University of Iowa of 1918: Polychaetous Annelids. Univ. Iowa Stud. Nat. Hist., 10: 3-23.

Tsurumi, M. and H.M. Reiswig. - 1997. Sexual versus asexual reproduction in an oviparous rope-form sponge, Aplysina cauliformis (Porifera: Verongida). Invertebr. Reprod. Dev., 32: 1-9.

Uebelacker, J.M. - 1984. Family Syllidae Grube, 1850. Volumen IV: 1-151. In: J.M. Uebelacker, and P. Johnson (eds.) Taxonomic guide to the polychaetes of the Northern Gulf of Mexico. Final report to the Minerals Management Service. pp. 1453. Barry A. Vittor y Associates, Inc. Alabama.

Verrill, A.E. - 1900. Additions to the Turbellaria. Nemertina and Annelida of the Bermudas with revisions of some New England genera and species. Trans. Connec. Acad. Arts Sci., 10: 595-671.

Williams, C. - 2009. The secret weapon. www.champwilliams.com/ limpet_high_res.html

Scient. ed.: D. Vaqué.

Received October 8, 2010. Accepted May 3, 2011.

Published online October 5, 2011. 